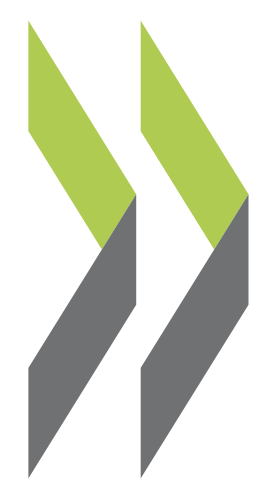

OECD Economics Department Working Papers No. 1034

Labour Market, Welfare Reform and Inequality in the United Kingdom

Christophe André,

Clara Garcia, Giulia Giupponi, Jon Pareliussen 


\section{Unclassified}

ECO/WKP(2013)26

Organisation de Coopération et de Développement Économiques

Organisation for Economic Co-operation and Development

08-Mar-2013

ECONOMICS DEPARTMENT

English - Or. English

\section{LABOUR MARKET, WELFARE REFORM AND INEQUALITY IN THE UNITED KINGDOM}

ECONOMICS DEPARTMENT WORKING PAPERS No. 1034

By Christophe André, Clara Garcia, Giulia Giupponi and Jon Kristian Pareliussen

All Economics Department Working Papers are available through OECD's Internet website at http://www.oecd.org/eco/Workingpapers

JT03336031

Complete document available on OLIS in its original format

This document and any map included herein are without prejudice to the status of or sovereignty over any territory, to the delimitation of international frontiers and boundaries and to the name of any territory, city or area. 


\section{ABSTRACT/RÉSUMÉ}

\section{Labour market, welfare reform and inequality in the United Kingdom}

Employment has risen by more and unemployment has risen less than expected, given the path of output. Nevertheless, long-term and youth unemployment and involuntary part-time work are high. A polarised labour market risks worsening income inequality, which is high by OECD standards, despite a recent and likely temporary decline. The UK welfare system is an essential safety net, which needs to promote employment, while protecting the most vulnerable. The reformed welfare system, Universal Credit, and the employment programme for disadvantaged workers, Work Programme, will generally improve work incentives and provide support for return to work, but need to be refined. Skill deficiencies are holding back employment and fostering inequality, as low education achievements penalise children from lower socio-economic backgrounds. Vocational training needs to be strengthened and cooperation with employers reinforced. Transition from education to work can prove challenging, requiring more attention to the integration of university graduates into the labour market.

JEL Classification: $J 21 ; J 24 ; 138$.

Key words: Labour market; Productivity; Activation policies; Workforce skills; Vocational training; Inequality; Welfare reform; Universal credit; Work incentives; Childcare costs; United Kingdom.

This working paper relates to the 2013 OECD Economic Survey of the United Kingdom. (www.oecd.org/eco/surveys/United Kingdom).

$* * * * * * * * * * * * * * * * * * * * * * * * * * * * * * * * * * * * * *$

\section{Marché du travail, réforme de la protection sociale et inégalités au Royaume-Uni}

L'emploi a progressé plus et le chômage a augmenté moins que prévu au regard de l'évolution de la production. Néanmoins, le chômage de longue durée et le chômage des jeunes, ainsi que le travail à temps partiel involontaire, sont élevés. La polarisation du marché du travail risque d'accentuer les inégalités de revenu, qui sont très marquées par rapport aux autres pays de l'OCDE, malgré une atténuation récente et probablement temporaire. Le système de protection sociale du Royaume-Uni constitue un filet de sécurité essentiel, qui doit favoriser l'emploi tout en protégeant les plus vulnérables. Le système réformé de protection sociale (Universal Credit) et le programme d'emplois pour les travailleurs défavorisés (Work Programme) renforceront généralement les incitations à travailler et faciliteront le retour à l'emploi, mais des améliorations sont nécessaires. L'insuffisance des qualifications bride l'emploi et creuse les inégalités, de faibles niveaux d'instruction pénalisant les enfants issus de milieux socio-économiques défavorisés. Il est indispensable de développer la formation professionnelle et la coopération avec les employeurs. Le passage de l'école à l'emploi est parfois difficile, d'où la nécessité de prêter une plus grande attention à l'intégration des diplômés de l'université sur le marché du travail.

Classification JEL : J21; J24; 138 .

Mots clefs : Marchés du travail; Productivité; Politiques d'activation; Qualification de la main d'œuvre; Formation professionnelle; Inégalités; Réforme de la protection sociale; Crédit Universel; Incitations à travailler; Frais de garde d'enfants; Royaume-Uni.

Ce document de travail se rapporte à l'Étude économique de l'OCDE du Royaume-Uni 2013 (www.oecd.org/eco/etudes/Royaume-Uni).

You can copy, download or print OECD content for your own use, and you can include excerpts from OECD publications, databases and multimedia products in your own documents, presentations, blogs, websites and teaching materials, provided that suitable acknowledgment of OECD as source and copyright owner is given. All requests for commercial use and translation rights should be submitted to rights@oecd.org. 


\section{TABLE OF CONTENTS}

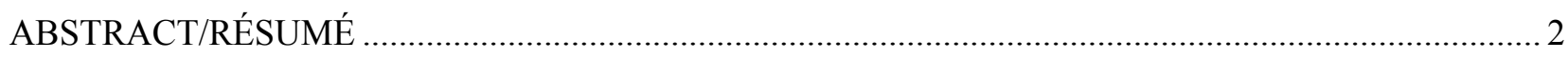

LABOUR MARKET, WELFARE REFORM AND INEQUALITY IN THE UNITED KINGDOM ........... 5

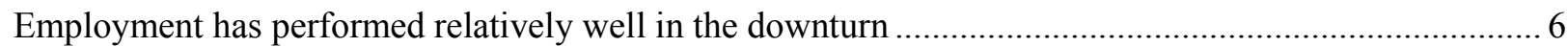

The fall in employment has been limited relative to output losses..................................................... 9

A flexible labour market dampened the impact of the recession on employment.................................... 11

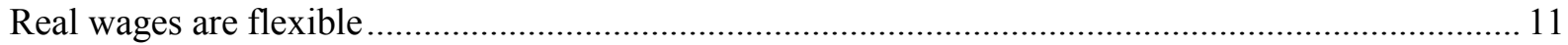

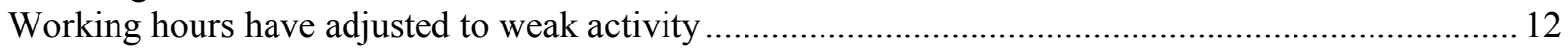

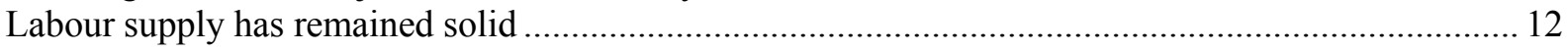

Labour market developments have increased inequality...................................................................... 13

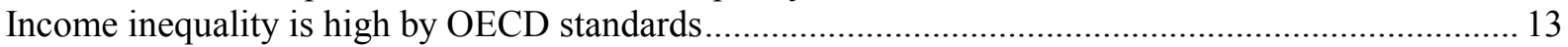

Inequality is mainly driven by differences in market income............................................................. 14

Taxes and benefits have a significant but declining redistributive impact ........................................ 16

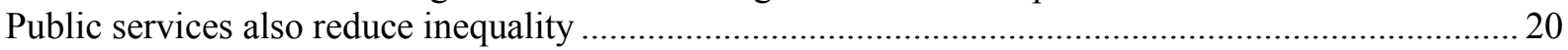

Welfare policies to promote employment while protecting the most vulnerable .................................... 22

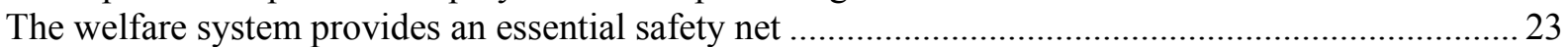

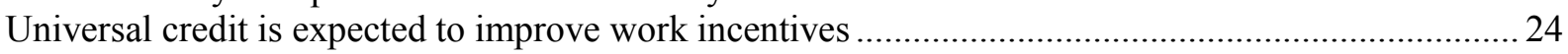

The Work Programme is a significant step forward, but activation policies are facing

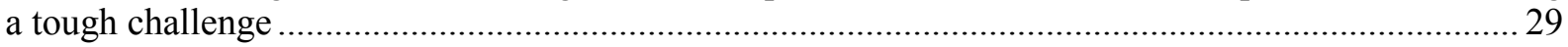

Skill deficiencies are also holding back employment and fostering inequality..................................... 32

Low education achievements penalise children from lower socio-economic backgrounds .................. 32

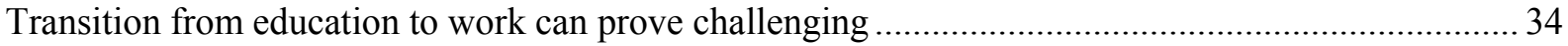

Vocational training needs to be strengthened and cooperation with employers reinforced ................... 35

Integration of university graduates into the labour market also deserves attention.................................36

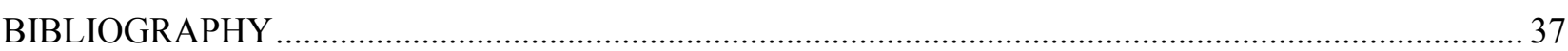

\section{Figures}

1. Long-term and youth unemployment and involuntary part time................................................... 7

2. Labour market developments compared to previous recessions ..................................................... 10

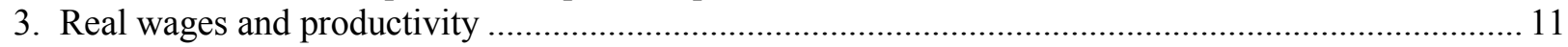

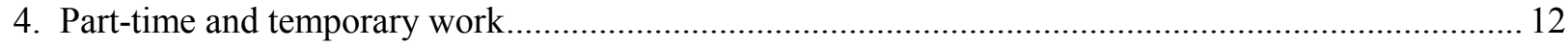

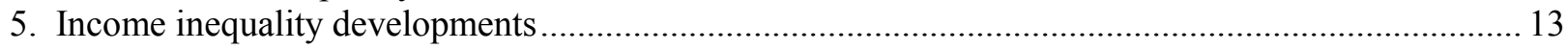

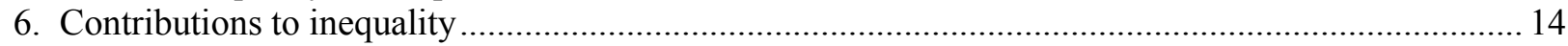

7. Changes in annual hours worked and in hourly real wages by earnings quintile ............................... 16

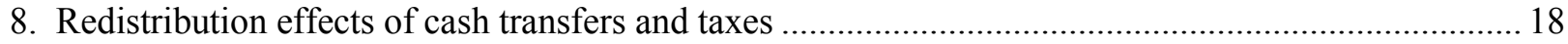

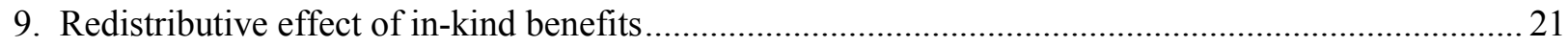

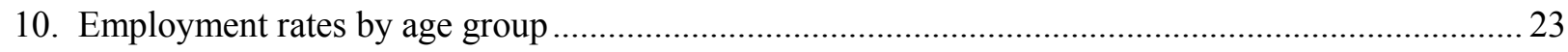

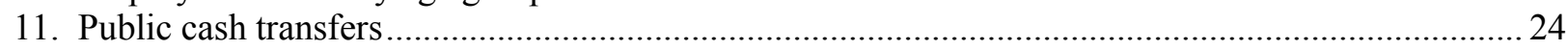

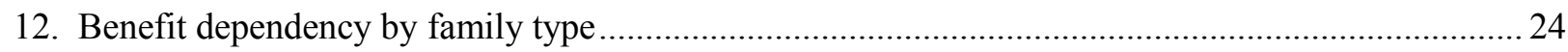

13. Incentives to work for a primary earner in a couple with children................................................. 26

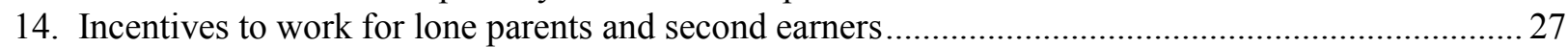

15. Eligibility to unemployment benefits and disability benefits recipiency ....................................... 30

16. Relative earnings from employment by level of educational attainment ......................................... 33

The statistical data for Israel are supplied by and under the responsibility of the relevant Israeli authorities. The use of such data by the OECD is without prejudice to the status of the Golan Heights, East Jerusalem and Israeli settlements in the West Bank under the terms of international law. 


\section{ECO/WKP(2013)26}

\section{Boxes}

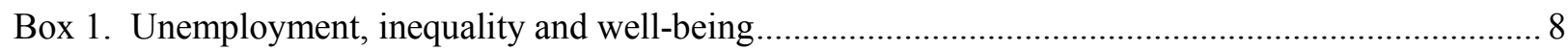

Box 2. Tackling fuel and water poverty in the United Kingdom ..................................................... 18

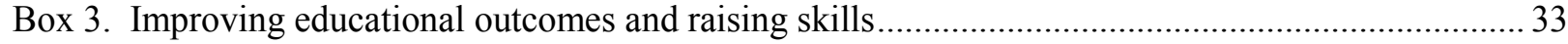




\title{
Labour market, welfare reform and inequality in the United Kingdom
}

\author{
By Christophe André, Clara García, Giulia Giupponi and Jon Pareliussen ${ }^{1}$
}

Unemployment has risen as a result of the recession and weak recovery, but less than during previous downturns in relation to output. A flexible labour market and real wages responding to productivity developments have dampened the impact of economic weakness on layoffs. Nevertheless, involuntary part-time work has increased significantly and long-term and youth unemployment are at historically high levels. Long spells out of work are likely to affect durably the level of skills and career prospects of many individuals, which could lower the productive potential of the economy and increase income inequalities, which are already high by OECD standards.

Welfare policies need to protect the most vulnerable, while avoiding creating unemployment and poverty traps. Universal Credit, a welfare reform that replaces a number of disparate benefits for workingage individuals by a universal benefit with a single taper rate, is a significant step forward in rationalising the benefit system and enhancing work incentives. However, better work incentives for lone parents and second earners are needed. The Work Programme supports return to work for benefit claimants facing significant disadvantages, including disabled people. Still, earlier, independent work capability assessments could reduce sickness-related absences and prevent more people from falling into disability benefits. High youth and long-term unemployment call for specific actions to prevent lasting exclusion from the labour market and to facilitate reallocation of the workforce as the economy undergoes structural change.

Strategies to reduce inequality and poverty are rightly focussing on promoting work and offering people opportunities to improve their standards of living, limiting reliance on government transfers. But increases in in-work poverty show that being employed does not necessarily guarantee a decent level of income. Sluggish economic growth and low productivity have pushed involuntary part-time employment up and real wages down, weighing particularly on the incomes of the least qualified segments of the workforce. To avoid a further rise in inequality, both higher employment and stronger labour productivity growth are needed. Achieving this goal requires enhancing the skills of the workforce, both through initial education, especially giving early support for disadvantaged children, and through training, apprenticeships and labour market interventions.

The paper is organised as follows. The first two sections describe labour market trends and main drivers behind these trends; the next section investigates the impact of labour market developments on income inequality; the following section assesses welfare policies to promote employment and protect the most vulnerable, with a special focus on Universal Credit and the Work Programme. The final section outlines policies to enhance the skills of the workforce.

1. Christophe André, Clara García and Jon Pareliussen are members of the Economics Department of the OECD and Giulia Giupponi was a consultant on this project. This paper is based on Chapter 1 of the OECD Economic Survey of the United Kingdom 2013, which was prepared under the responsibility of the Economic and Development Review Committee (EDRC). The authors would like to thank Henrik Braconier, Nicola Brandt, Anthony Cox, Andrew Dean, Robert Ford, Michael Förster, Brendan Gillespie, David Grubb, Brendan Price, Christopher Prinz, Linda Richardson, Piritta Sorsa and other OECD colleagues, members of the UK administration and EDRC delegates for useful discussions, comments and suggestions, and Deirdre Claassen for excellent editorial support. Further analysis of the reform of the benefit system in the United Kingdom is provided in a companion paper (Pareliussen, 2013). 


\section{Employment has performed relatively well in the downturn}

The global economic and financial crisis and the recession that followed have pushed the unemployment rate from around $5 \%$ on average over the period $2000-2007$ to about $81 / 2$ per cent by end2011. Unemployment has receded somewhat since then and now stands at slightly below $8 \%$, which is close to the OECD average, and nearly 4 points below the euro area average.

The breakdown by activity partly explains the profile of the unemployed and the evolution of regional differences. As construction and manufacturing are predominantly male activities, the unemployment rate increased more for men than for women during the recession. Northern regions with a larger share of production jobs face larger unemployment than the more service-oriented Southern regions during the downturn. This evolution is likely to endure, as cuts in public jobs will affect the North proportionately more than the South.

While the rise in total unemployment has been more contained than most observers had feared, some trends are preoccupying. Long-term and youth unemployment, and involuntary part-time work have increased markedly, now reaching respectively about 900 000, 950000 and 1.4 million (Figure 1, Panel A). The long-term unemployment rate was below the OECD average in 2007, but slightly higher by 2011. It remains, however, significantly below the European Union (EU15) average (Figure 1, Panel C). Youth unemployment is somewhat higher than in the EU15 and well above the OECD average, although this figure includes around 300000 full-time students (about 30\% of the total), which makes international comparisons difficult (Figure 1, Panel D). The youth as entrants to the labour market are traditionally amongst the worst hit by recessions. But youth unemployment started to increase before the recession, suggesting a more structural problem.

Another worrying trend is that the number of youth not in employment, education or training (NEETs) has been on a rising trend and is among the highest in Europe, being only surpassed in some southern EU countries, Turkey and Ireland (Figure 1, Panel B). It is also worth noting that the proportion of men in all NEETs in England has increased from around 40\% in the early 2000s to $48 \%$ in mid-2012. The large number of NEETs raises fears of a "lost generation", with lasting exclusion from work causing permanent scars for the individuals involved, weakening the long-term economic growth potential as human capital erodes, and undermining social cohesion. Furthermore well-being losses associated with high unemployment and inequality are substantial (Box 1). 
Figure 1. Long-term and youth unemployment and involuntary part time
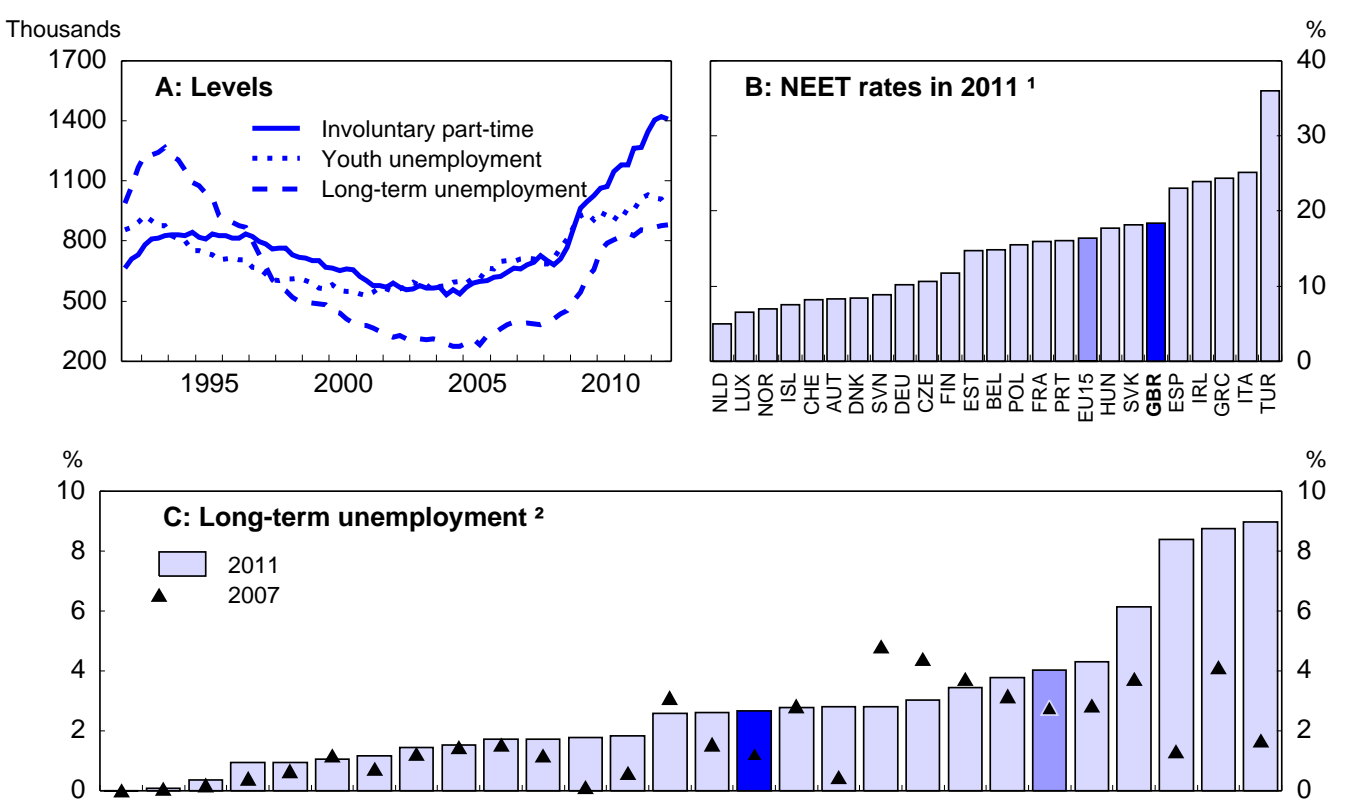

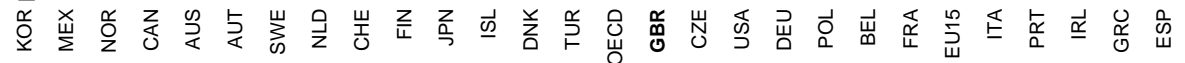

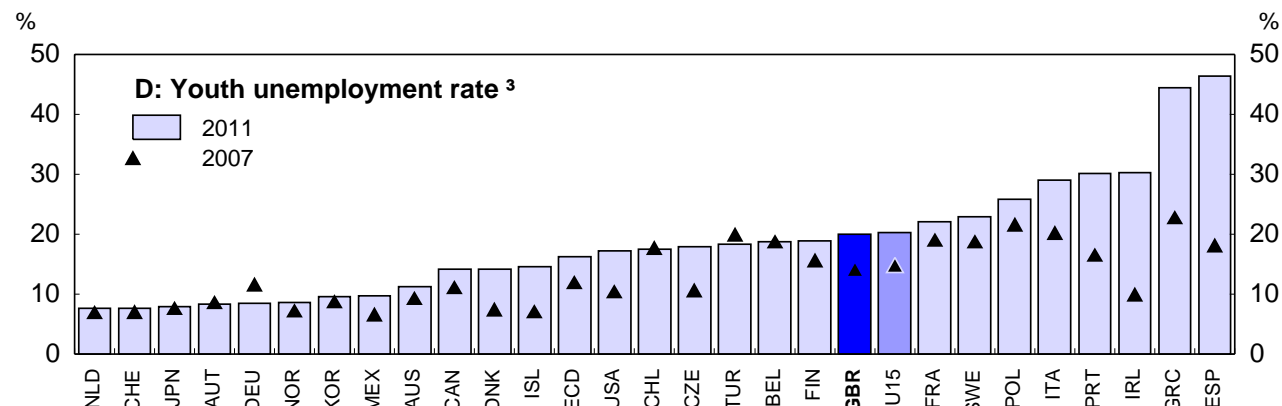

1. People aged 18 to 24 not in education, employment, or training.

2. Duration of unemployment longer than one year; as a percentage of the labour force.

3. Aged 15 to 24 .

Source: Office for National Statistics, Eurostat and OECD Labour Force Statistics database. 


\section{Box 1. Unemployment, inequality and well-being}

Measurement of societal well-being has been subject to large and growing attention, as a number of initiatives at the international level have highlighted the importance of going beyond GDP to evaluate economic performance and social progress (Stiglitz, Fitoussi and Sen, 2009). On top of reviews from multilateral institutions, such as the European Commission or the OECD, the United Kingdom has undertaken a national consultation to gather views on a wider concept of well-being, which will cover quality of life, environmental sustainability, as well as economic performance. This programme is being led by the Office for National Statistics, with final results scheduled for 2013. Preliminary findings from a consultation questionnaire have identified issues that matter most to British people, which include labour market aspects like availability of employment and job satisfaction (ONS, 2012). This box discusses the potential implications of the current weak labour market situation on well-being.

The relative importance of potential drivers of well-being has been extensively discussed (OECD, 2011a; Fleche et al., 2011). The most influential factors in the United Kingdom are, in this order, self-reported health, employment status, perceived freedom of choice and the state of the environment. Indicators of material living standards, such as income or wealth, have a much smaller effect, in line with other OECD countries. All else equal, doubling income increases average wellbeing by only 0.1 units, in a scale of life satisfaction ranging from 1 to 10 . This compares to larger well-being losses associated to becoming unemployed, 0.45 points, or gains from perceived health, for which a one point improvement (for example, from good to very good health) yields a 0.5 points increase in life satisfaction. A one point increase in perceived income inequality (on a scale of 10 ) reduces life satisfaction by 0.1 points. This is lower than the OECD average, but consistent with findings in other Anglo-Saxon countries (di Tella et al., 2001).

Unemployment has a negative impact on well-being through the related income loss. However, the literature provides clear evidence that unemployment operates also through non-pecuniary channels. Even after controlling for income and other factors, several studies find that the unemployed are less happy than the employed (Di Tella et al., 2001; Bohnke, 2006; Bell and Blanchflower, 2009). As shown by Goldsmith et al. (1996), unemployment is responsible for depression, anxiety, loss of self-esteem and personal control, which all reduce well-being. The duration of unemployment also matters, since well-being deteriorates as unemployment spells increase. Compared to pre-crisis levels, unemployment duration has increased substantially. Currently $35 \%$ of the unemployed have been unemployed for more than a year, 10 percentage points more than the pre-crisis level, inducing subsequent losses in well-being. Finally, rises in the unemployment rate do also affect the employed, primarily because of the increasing risk of becoming themselves unemployed (Clark, 2003).

A weak labour market can affect the working conditions of those in employment, with a negative impact on their well-being. Well-being deteriorates when the number of hours worked is below the level wished for. The UK Annual Population Survey reveals that involuntary part-timers incur welfare losses comparable to those suffered by the unemployed. A plausible explanation is that work helps fulfil the needs of social inclusion, status, self-esteem and engagement in collectively meaningful activities (Jahoda, 1982 and OECD, 2011b). Since the beginning of the crisis, the share of involuntary part time has almost doubled, reaching $18 \%$ of part-time employment in the first quarter of 2012. Male part-timers seem to be particularly affected, as one in two men aged between 25 and 49 working part time would like to work full time. Job insecurity is also related to a decline in wellbeing comparable to that experienced by the unemployed. The OECD's Better Life Index uses the percentage of employees on temporary contracts as a proxy for job insecurity. Though the United Kingdom registers a low share of temporary workers by international standards, the number of temporary workers that could not find a permanent job has surged since the crisis started, reaching $40 \%$ in 2012 after having remained broadly stable around $25 \%$ in the 2000 s.

The worsening of the labour market situation has been unequally distributed across the labour force, as around one third of the increase in the unemployment stock has been borne by those aged 18 to 24 , although they only represent one in eight in the labour force. Entering the labour market at a relatively bad time may have life-long implications that go beyond the loss of income, and affect broader determinants of well-being, such as skills depreciation, weak integration in the labour market and low self-esteem.

People with low education levels are most affected by unemployment. Those with no qualifications or below upper secondary education (level 3) accounted for $64 \%$ of the unemployed in England in 2008, while they only represented $45 \%$ of economically active adults. Low qualified young people are particularly at risk of unemployment. In 2011, 12.8\% of 24-year olds with only GCSEs were unemployed in the United Kingdom, while the corresponding rate for A-level and university degree holders were respectively $6.7 \%$ and $4.9 \%$. The recession has worsened the relative situation of low-skilled 
youth, as demand for labour from some of their traditional employers, such as retail trade and hotels and restaurants, has shrunk, even though it has recovered somewhat since 2010. Furthermore, they are facing increasing competition from recent graduates, more than a third of which are now employed in low-skill jobs.

As growth is expected to remain sluggish, unemployment could rise further in the near term. Fiscal consolidation involves large job cuts in the public sector. The Office for Budget Responsibility (OBR) projects a fall in general government employment of around 929000 (excluding the impact of reclassifications in the education sector) between the start of 2011 and 2018, although it expects this to be more than offset over time by an increase in market sector employment of around 2.2 million over the same period (OBR, 2012). As private sector employment currently is high in relation to output and involuntary part-time work is common, many firms may respond to higher demand by increasing hours worked by employees and using their workers at full potential, thereby increasing productivity, before hiring more workers.

\section{The fall in employment has been limited relative to output losses}

Employment has been surprisingly resilient given the depth of the recession. While output remains more than 3\% below pre-crisis levels, employment has declined far less than during the recessions of the 1980s and 1990s, even though those were shallower and shorter and output had already surpassed its pre-crisis level at this stage of the cycle (Figure 2, Panel A and B). A reduction in the number of hours worked per employee has contributed to good employment outcomes, although it has not been larger than in previous downturns (Figure 2, Panel C). 
Figure 2. Labour market developments compared to previous recessions Deviation from the peak ${ }^{1}$
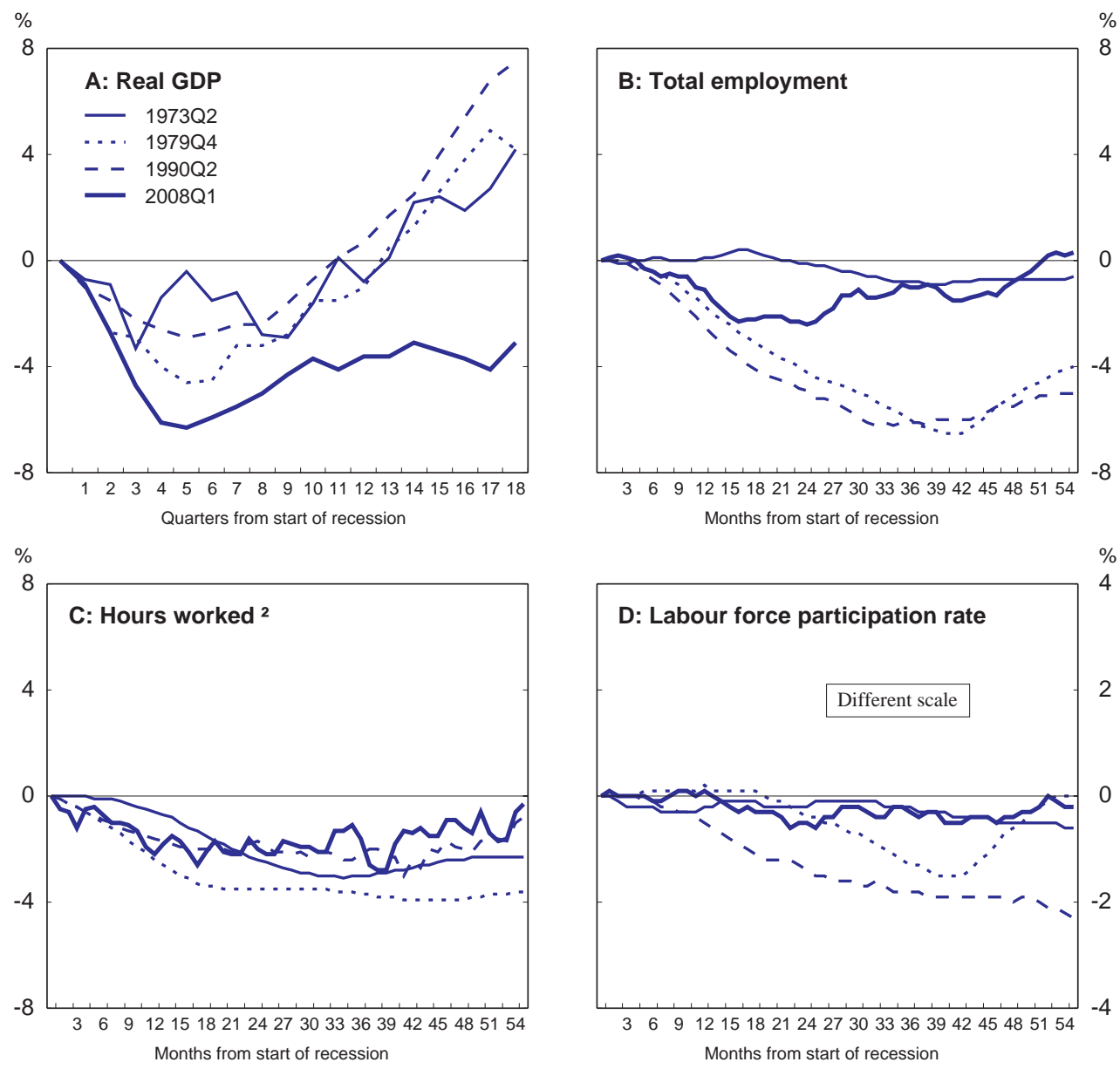

1. Percentage change for real GDP, total employment and hours worked. Change, in percentage points, for labour force participation rate.

2. Total actual weekly hours per worker.

Source: Office for National Statistics.

From an international perspective, the United Kingdom's employment contraction has also been modest relative to output developments. Countries which have experienced similar output losses as the United Kingdom since 2008, such as Denmark and Spain have suffered worse percentage falls in employment. The United States has experienced a far greater contraction in employment despite a much stronger output recovery.

Employment losses have been concentrated in construction and manufacturing. The decline in construction employment looks essentially cyclical. In manufacturing, the recession has prolonged a longterm declining trend in employment. These trends have affected more men than women during 2008 and the first half of 2009. The service sector has continued to create jobs, although at a slow pace and with subsector differences. Wholesale and retail trade, transport, accommodation and food services, and finance and insurance were the worst hit. Public administration, health and education have seen the largest increases in employment over the past four years, but this trend is already being altered by cuts in public jobs, that are expected to continue going forward. This is likely to affect more women than men given the high female employment rates in these sectors. High uncertainty about the strength of the recovery is also 
likely to hold back employment growth. In particular, the euro area crisis is bound to hamper hiring in export industries.

\section{A flexible labour market dampened the impact of the recession on employment}

The flexibility of the UK labour market contributes to explaining the relatively limited losses in overall employment over recent years. Real wages have fallen. Part of the adjustment in labour utilisation has gone through a reduction in hours worked, limiting job losses. Furthermore, there have been fewer exits from the labour force into early retirement and inactivity than during the 1990s recession, which increases unemployment in the short term but contributes to preserving human capital and limiting social exclusion in the longer term.

\section{Real wages are flexible}

Real wages have fallen during the downturn, as moderate increases in nominal wages were outpaced by price inflation (Figure 3, Panel A). The adjustment of real wages to lower productivity has been greater than in many other countries where productivity has fallen (Figure 3, Panel B). This contrasts with the early 1990s, when hourly real wages increased, prompting firms to reduce their workforce. In the current downturn, the fall in the relative price of labour has been a major factor in allowing employers to limit layoffs, especially of skilled workers who are difficult to hire, or expand labour intensive activities, while preserving profit margins. Relative wage flexibility across sectors and occupations also helps reallocation of labour in an economy which needs rebalancing.

A number of factors could explain recent evolutions of wages (Faccini and Hackworth, 2010). Rising inflation may have facilitated the adjustment of real wages in the presence of downward rigidity in nominal wages. High unemployment expectations may have persuaded more employees to trade lower real wages for job security. Labour supply has remained strong due to steady participation and immigration, putting downward pressure on wages. Along with declining relative labour costs, it is likely that low interest rates and strong corporate balance sheets have helped companies maintain employment. The number of insolvencies and related job losses has also been much smaller than in previous recessions.

Figure 3. Real wages and productivity ${ }^{1}$
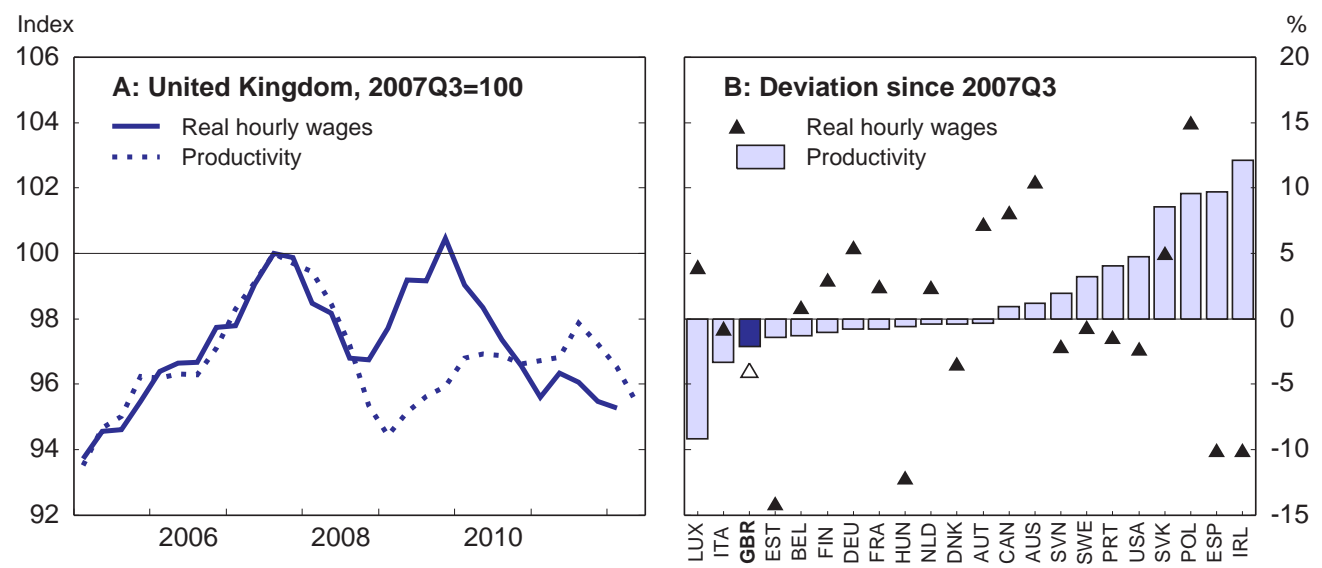

1. Real wages refers to compensation of employees divided by hours worked, and deflated by consumer prices. Productivity refers to real GDP divided by total employment.

Source: Office for National Statistics and OECD Economic Outlook 92 database. 


\section{Working hours have adjusted to weak activity}

Adjustments in working hours have also limited rises in unemployment. While the number of full time jobs is well below pre-crisis levels and has been broadly flat over the past two years, in line with GDP, the number of temporary and part-time jobs has increased (Figure 4, Panel A). Involuntary part-time work has risen sharply to 1.4 million in mid-2012 and, as a share of total employment, was close to the EU15 average in 2011 (Figure 4, Panel B). Part-time employment limits the number of unemployed people during downturns, reduces income losses, the burden on welfare and social exclusion. It may also mitigate the long-term consequences of prolonged slumps. Part-time jobs may provide relevant experience and skills, which could improve employment prospects when labour market conditions improve.

Nevertheless, short working hours in low qualified jobs can lead to in-work poverty, as on average part-timers work less than half the number of hours of full-timers and earn less than a third of their salary. The increase in involuntary part-time work during the downturn has been mainly in low-paid jobs. Part-time unemployment is more likely to be involuntary for people with lower educational and occupational levels (Cam, 2012). Even though involuntary part-time work has increased for both genders, the rise is particularly sharp for men. One in two men aged between 25 and 49 working part time would like to work full time. Involuntary part-time work also affects high unemployment areas more, contributing to widening the income gap between regions.

Figure 4. Part-time and temporary work
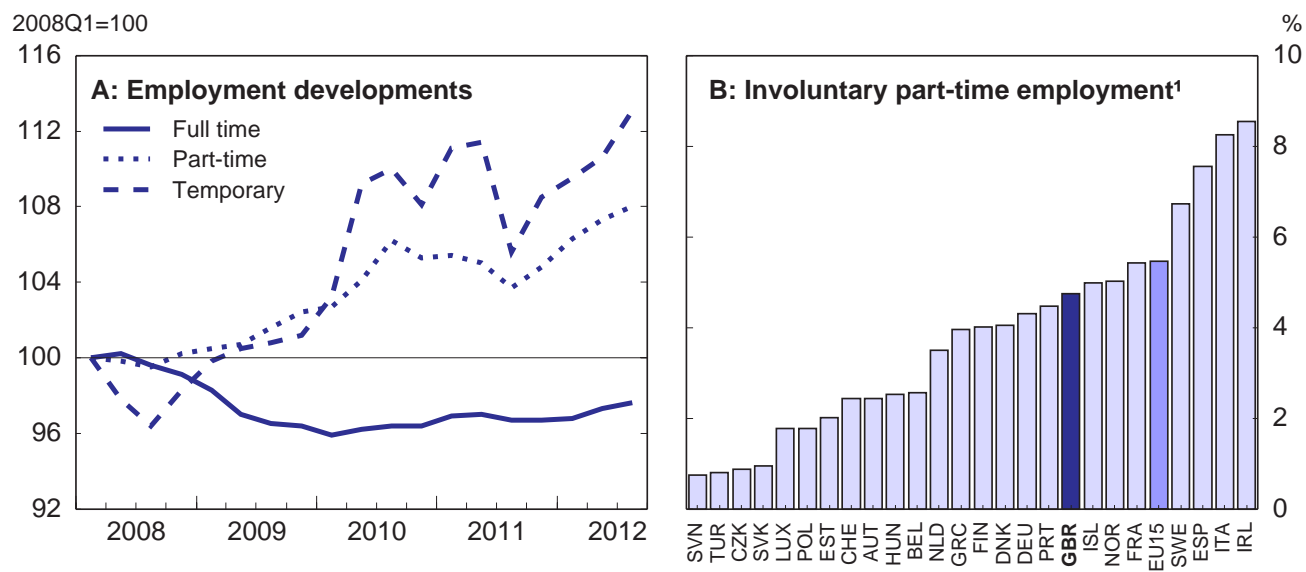

1. As a percentage of total employment. Refers to 2011.

Source: Office for National Statistics and Eurostat.

\section{Labour supply has remained solid}

High unemployment often leads to a fall in labour force participation. As job opportunities are scarce, some people find it less attractive to get involved in the labour market. For instance, older people might retire or young people stay longer in education. Some workers drop from the labour force, as they become discouraged and no longer search for work. The decline in participation was particularly marked in the 1990 s recession, with a fall of $2.5 \%$ of the working-age population.

The participation rate has remained roughly constant through the current downturn (Figure 2, Panel D). In particular, labour participation of older people has remained high during the downturn, as early retirement packages are less generous than in the 1990s, pathways to early retirement through disability benefits have become more restrictive and concerns have risen about levels of pensions from defined contribution schemes following losses in financial wealth in recent years (Banks et al., 2011; Faccini and Hackworth, 2010). Low real wages and job insecurity might also have supported work participation, for example of second earners. Higher participation of older workers both preserves the productive capacity of the economy and potentially alleviates the long-term burden on public finances. 


\section{Labour market developments have increased inequality}

The flexibility of the labour market has contained the increase in unemployment during the sharpest output contraction in the post-war period. However, this has come at the price of large underemployment and lower wages, especially for low-skilled workers. Current labour market conditions are widening the income gap between full-time employees and an increasing share of the workforce on parttime, insecure and often low-paid jobs. This comes in a context where income inequality, measured by the Gini coefficient of disposable income, was already high and rising before the recession. Although inequality fell in 2010-11, as the fall in real incomes was larger at the top of the income distribution than at the bottom, absolute poverty increased (Cribb et al., 2012). Moreover, social transfers are being cut significantly.

Policies need to protect the most vulnerable to maintain social cohesion and prevent lasting damage from the recession on people's life and the productive capacity of the economy. Furthermore, high inequality could encourage household indebtedness, thereby threatening financial stability (Kumhof and Rancière, 2010). Perceived fairness is also important to ensure public support for the necessary fiscal consolidation effort, which will need to be sustained over a protracted period.

\section{Income inequality is high by OECD standards}

The recession has exacerbated a rising trend in income inequality across the OECD (Figure 5). The ratio of the average income of the richest $10 \%$ of the population relative to the poorest $10 \%$ is now 10 to 1 in the United Kingdom, above the OECD average of 9 to 1, but significantly below the United States (about 14 to 1). From the mid-1980s to the late 2000s, real household income increased at an annual rate of $2.5 \%$ in the top decile but only $0.9 \%$ in the bottom decile. This is one of the widest income growth gaps in the OECD, exceeded only in Israel and Sweden (although Sweden remains a low inequality country).

Figure 5. Income inequality developments ${ }^{1}$

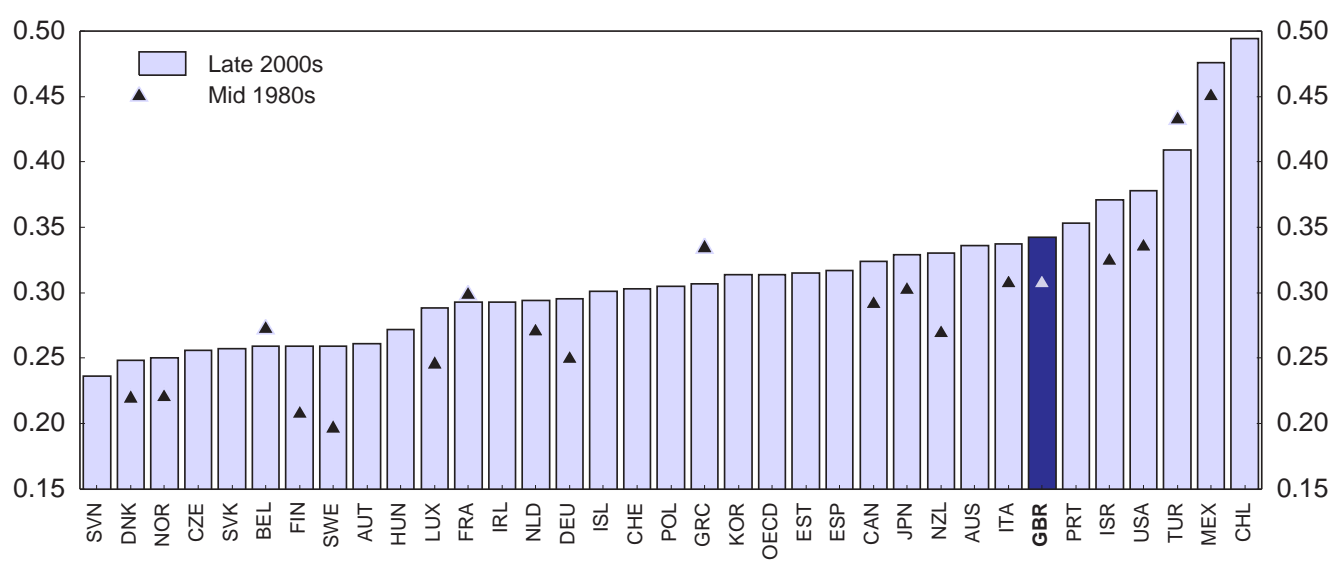

1. Measured by the Gini coefficient based on equivalised household disposable income, after taxes and transfers.

Source: OECD database on Household Income Distribution and Poverty.

The underlying causes of rising inequality are complex. Potential drivers are globalisation, technological change, and product and labour market institutions, policies and regulations. Globalisation has increased the global supply of low-skilled labour, affecting wages and employment prospects of workers with low qualifications. At the same time, more intense international competition for high-skilled workers has pushed up top incomes. Advances in information and communication technology (ICT) are also favouring high-skilled workers, whose task cannot be easily automated, and thereby increasing inequality (Kierzenkowski and Koske 2012). Some studies suggested technological change is a more powerful driver of inequality than globalisation (IMF, 2007; OECD, 2007a). However, disentangling these 
influences is difficult, as technology is a major determinant of the organisation of international supply chains (OECD, 2011c). Reforms undertaken by most OECD countries, including the United Kingdom, since the 1980s to increase competition in product markets and make labour markets more flexible have generally been positive for employment, which tends to reduce inequality, but have also widened wage disparities. These opposite effects tend to offset each other (OECD, 2011c).

\section{Inequality is mainly driven by differences in market income}

The main contribution to income inequality comes from the dispersion of market income, partly offset by redistribution through the tax and benefit system. This pattern is observed across OECD countries and has not changed much over time (Figure 6, Panel A). The main contribution to inequality is from wages and salaries (Figure 6, Panel B). While revenues from capital and self-employment are less evenly distributed than wages and salaries, their smaller share in disposable income imply a lower contribution to inequality.

Figure 6. Contributions to inequality ${ }^{1}$
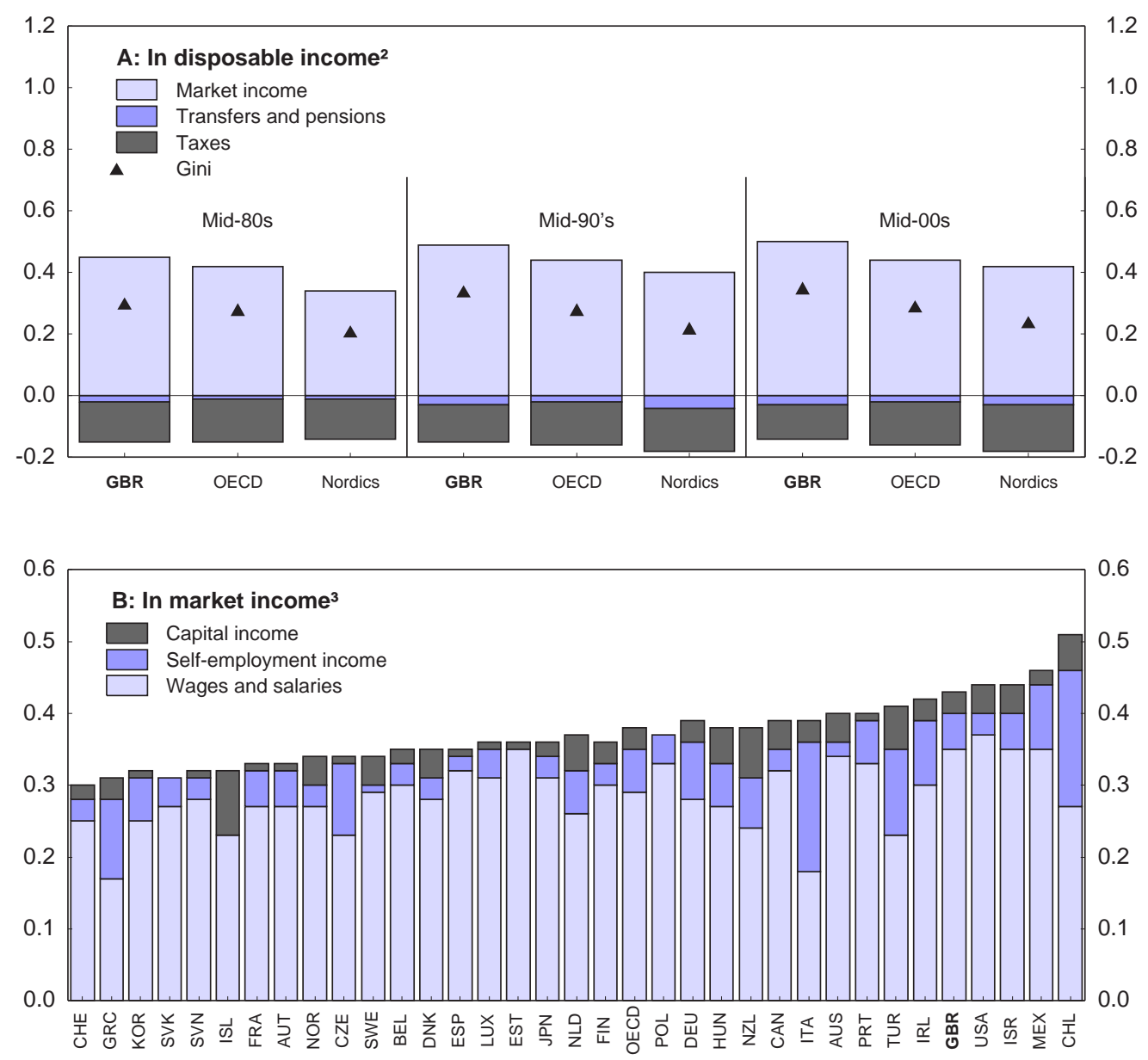

1. Inequality measured by the Gini coefficient; a higher value indicates higher inequality.

2. Countries for which data are available.

3. The data for Greece, Hungary, Mexico and Turkey are net of taxes. Data for France and Ireland refer to the mid-2000s.

Source: OECD (2011), Divided We Stand: Why Inequality Keeps Rising, OECD Income Distribution and Poverty, OECD Social Expenditure Statistics database. 
Inequality among wage earners results both from hourly wage dispersion and from differences in hours worked. Wage dispersion in the United Kingdom is higher than in most other OECD countries. Between the mid-1980s and the mid-2000s, real hourly wages in the top quintile have increased at an annual rate of above $3 \%$, compared to $1.8 \%$ in the bottom quintile. This pattern is common across OECD countries, as seen from the average of a sample of OECD countries for which comparable data are available (Figure 7, Panel A). Wage dispersion is to some extent induced by structural trends in demand for labour, for instance linked to the falling share of industry, which provides many intermediate jobs. Low educational attainments also contribute to trapping an increasing share of the population in low-paid jobs. Hence, raising workforce skills will be necessary to reduce inequality, as discussed in the last section of this paper.

Earnings differentials are accentuated by the increasing difficulty for low-skilled workers to find full-time jobs. While the annual number of hours worked has risen by more than $9 \%$ in the top quintile between the mid-1980s and the mid-2000s, it has increased by little more than $3 \%$ in the bottom quintile. This gap is somewhat smaller than in a comparable OECD sample, where a modest rise in hours worked in the top quintile was accompanied by a substantial contraction in the bottom quintile (Figure 7, Panel B). The increase in involuntary part-time employment contributed to a marked increase in the polarisation of earnings, especially among working-age men. Difficult labour market conditions in the downturn are likely to increase polarisation further. High youth unemployment is also likely to increase income inequality, even beyond the short term, as a number of studies report a significant lasting effect of spells of unemployment on earnings (Arulampalam, 2000; Gregg and Tominey, 2005).

The only sizeable inequality-reducing factor has been female employment, which increased by nearly 20 percentage points since the mid-80s. Higher female employment generally reduces inequality across the OECD, though this depends on the extent to which women entering work are in couples with high or low earners. As employment rates increased similarly for wives of top and bottom earners, the reduction in inequality resulting from higher female employment has been fairly strong. It is worth noting, however, that a gender gap remains in terms of wages. Despite having narrowed by around 20 percentage points since the introduction of the Equal Pay Act in 1975, the gender gap in median hourly earnings for a full-time job is still at 9.1\% (ONS, 2011).

The gender pay gap, however, varies significantly depending on age, education level, company size and occupational type. Differently from 30 years ago, when the wage gap was already visible at entry in the labour market, nowadays it fluctuates around equality up to the age of 30 , then opens up and levels off around the age of 50. This pattern suggests that maternity is likely to be a relevant factor behind wage inequalities, especially as the number of dependent children increases. As stressed in the Final Report of the OECD Gender Initiative to the Ministerial Council Meeting 2012 (OECD, 2012a), mothers in the United Kingdom are particularly likely to work part-time to reconcile work and care issues, a decision partly imposed by the lack of access to and high costs of childcare. The expansion of quality childcare provision and out-of-school care could ease the transition to full-time positions. Encouraging gender equality and temporary use of part-time as a solution to childcare issues could promote continuous employment patterns and consequently close the wage differential that emerges from reduced working hours and fragmented careers. 
Figure 7. Changes in annual hours worked and in hourly real wages by earnings quintile ${ }^{1}$ Mid-1980s to mid-2000s
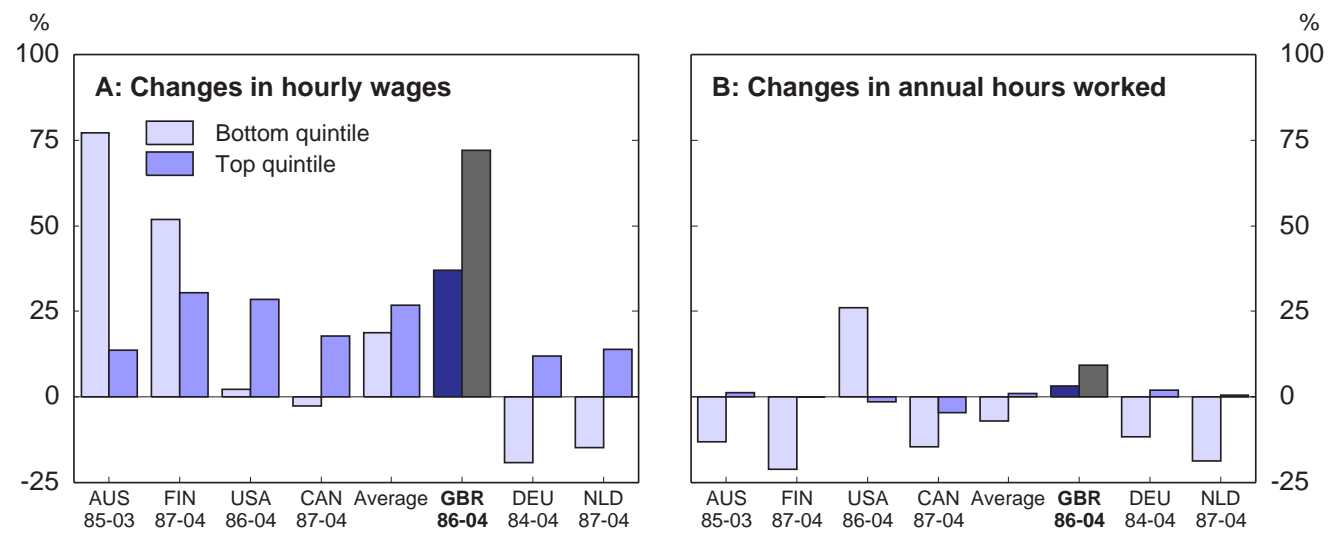

1. Samples are restricted to all paid workers (aged 25-64) with positive wages and positive hours worked during the reference year with information on annual hours worked. Mean wages in national currencies at constant 2005 values. Countries ranked in ascending order of changes in earnings inequality.

Source: OECD (2011), Divided We Stand: Why Inequality Keeps Rising.

\section{Taxes and benefits have a significant but declining redistributive impact}

Taxes and benefits reduce the Gini coefficient from 0.45 to 0.35 , which is similar to the average reduction in the OECD (Figure 8, Panel A). Government cash transfers to households contribute more than taxes to income redistribution (Figure 1.8, Panel B). Cash transfers in the United Kingdom are lower than the OECD average (Figure 11), but have strong redistributive power, as they include a smaller share of pensions and are more targeted towards low-income households than in the more universal systems prevailing in continental Europe and especially Nordic countries. Taxes play a smaller role than transfers in income redistribution, but the tax system nevertheless reduces inequality significantly. Even if tax schedules are not very progressive by OECD standards, the wide dispersion of market income results in significant redistribution through taxes.

Nevertheless, as in most other OECD countries, redistribution through the tax and benefit system has been increasingly unable to compensate for growing market-income dispersion, with redistribution offsetting only about one fourth of the increase in market income inequality between the mid-1980s and the mid-2000s. As means-tested benefits are the most redistributive instruments, policies have affected low-income households more than high income ones. As a result, relative poverty, measured as household incomes below $60 \%$ of median income, has been contained. Between 1996-97 and 2009-10, the proportion of individuals with household incomes below $60 \%$ of median income fell from $19.4 \%$ to $17.7 \%$ before housing costs and from $25.3 \%$ to $22.2 \%$ after housing costs. Relative child poverty fell from $26.7 \%$ to $19.7 \%$ before such costs, a reduction of over a quarter, but short of the previous government objective of halving relative child poverty by 2010 (Jin et al., 2011).

The gap between relative poverty rates before and after housing costs highlights the burden of housing costs in the United Kingdom. The housing cost overburden rate - the percentage of the population living in households where the total housing costs (net of housing allowances) represent more than $40 \%$ of disposable income (EU housing statistics) - is one of highest in the European Union (EU), reaching nearly $41 \%$ in 2009 for tenants in the private sector, compared to an EU27 average of $25 \%$. Recent cuts to housing benefits and the removal of indexation on actual market rents from April 2013 will increase the burden further for low-income tenants in private rental. As the supply of affordable housing is also expanding more slowly than demand, social renting is an increasingly restricted alternative. Fiscal 
consolidation since 2010 initially reduced inequality, as tax increases hit high-income households the most, but phased-in benefit cuts may have the opposite effect going forward (Jin et al., 2011).

Reforms to the tax system could contribute to lowering inequality. The council tax, which is regressive, should be replaced by a property tax based on market values, with safeguard mechanisms for housing rich but income poor households. As well as reducing inequality, this could improve the stability of the housing market (OECD, 2011a, Chapter 2). The reduced rate of VAT on domestic energy is an inefficient instrument to support low-income households, both from an economic and environmental point of view (OECD, 2011a, Chapter 4). Support for energy costs should be targeted towards low-income households. Similarly, Winter Fuel Payments, a tax free payment to help older people keep warm during winter, should be means-tested. The best way to alleviate energy poverty is through energy efficiency improvements, which should be encouraged (Box 2).

Given that the share of national income going to the top 1\% earners has doubled since 1970, raising marginal personal tax rates might look attractive. However, international studies suggest that increasing marginal tax rates on high incomes tends to lower taxable incomes significantly, as work effort decreases and tax avoidance and evasion increase (OECD, 2011c). Lower than expected tax receipts from the $50 \%$ income tax rate above $£ 150000$ in 2010-11 seem to confirm this finding (HMRC, 2012). Hence, the government strategy to restrict tax reliefs, close loopholes and fight tax evasion looks more promising than pushing up marginal tax rates. Active participation in the G20 and OECD sponsored Global Forum on Transparency and Exchange of Information for Tax Purposes can play a decisive role in the success of anti-evasion policies. Finally, the planned rise the State Pension age in line with increases in longevity will reinforce equity between generations. 

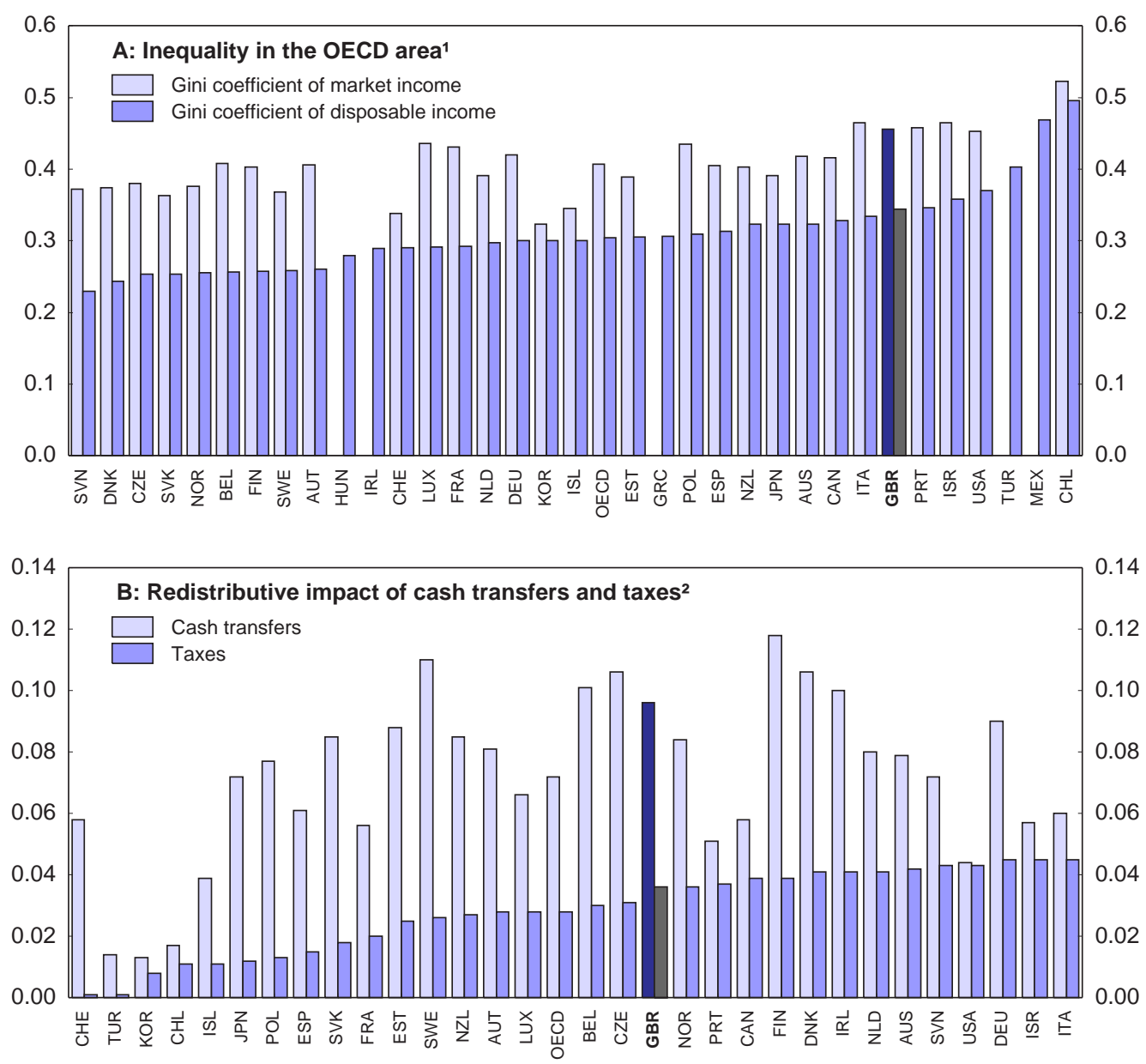

1. Late 2000s; working age population.

2. Point reduction in the Gini coefficients, in the late 2000s.

Source: OECD Income Distribution and Poverty Database.

\section{Box 2. Tackling fuel and water poverty in the United Kingdom}

Rising fuel and to a lesser extent water prices are putting an increasing burden on low-income households. The number of individuals in fuel poverty reported here is based on the Low Income High Costs (LIHC) indicator proposed by Hills (2012). Individuals are considered as fuel poor if they have required fuel costs that are above the median level and would be left with a residual income below the official poverty line if they were to spend that amount. The number of households in fuel poverty is of the same order of magnitude under the current official measure, where fuel poverty is defined by required fuel costs exceeding $10 \%$ of income. More than 7 million individuals in nearly 3 million households are affected in 2009 and the fuel poverty gap is $£ 1.1$ billion, defined as the amounts by which the assessed energy needs of fuel poor households exceed the threshold for reasonable costs (Hills, 2012). Current policies are estimated to reduce the fuel poverty gap by only $10 \%$. Furthermore, even though new policies are being put in place, fuel poverty is projected by the Hills Review to be higher in 2016 than in 2009, even assuming benign fuel price developments. Well designed policies to tackle fuel poverty, in addition to helping low-income households, would contribute to improving health and well-being through more adequate heating of some homes, and to reducing carbon emissions. This box concentrates on immediate fuel poverty relief and home energy efficiency improvements. In the longer term, promoting cost-effectiveness of energy generation, through competition and innovation is also decisive. 
Fuel poverty is clearly associated with energy inefficient homes, which in England concern three quarters of fuel poor households and $90 \%$ of the fuel poverty gap. Homes in the United Kingdom tend to be less energy efficient than in Germany, the Netherlands and Nordic countries. This results partly from the high proportion of houses relative to flats - houses account for $86 \%$ of the fuel poverty gap - and the age of the housing stock - properties built before 1945 represent over a third of the housing stock and account for two thirds of the fuel poverty gap (Hills, 2012). In addition, energy efficiency standards appeared as late as 1995 in UK building regulations, compared to the late 1950s or early 1960s in Scandinavian countries (Laustsen, 2008). Low energy efficiency of homes is also a major concern from a climate change mitigation point of view, as households account for $20 \%$ of total greenhouse gas emissions (Bowen and Rydge, 2011).

The current fuel poverty policy package includes policies affecting prices, transfers and energy efficiency, but with a high weight on some poorly targeted income transfers and tax rebates. The largest single instrument in terms of funding is Winter Fuel Payments, a non means-tested benefit paid to all households with a member aged 60 or over. The VAT rate charged on domestic energy consumption is $5 \%$ instead of the standard rate of $20 \%$. Such measures incur high deadweight losses, as non-poor households also benefit, and generate incentives for higher energy consumption. They should be replaced by measures better targeted at low income households facing high energy costs.

The new Green Deal financial mechanism addresses restrictions to access to finance and will allow households to improve the energy efficiency of their properties at no upfront cost, with the investment being paid by a charge on electricity bills. However, as the Green Deal is not targeted on fuel poor households, its impact on fuel poverty will depend on the proportion of the latter that will participate and especially receive subsidies through the Affordable Warmth obligation of the Energy Company Obligation (ECO). The ECO requires energy suppliers: $i$ ) to contribute to carbon savings in the household sector, which they are likely to do mainly through financing solid wall insulation (carbon obligation); ii) to reduce energy bills for some low-income and vulnerable households through financing energy-efficiency improvements (Affordable Warmth obligation). Households not taking part in the Green Deal will face higher energy bills, as the cost of subsidies and administration are expected to be passed through to customers by energy suppliers. To ensure that fuel-poor households are not left behind as overall energy efficiency improves, it is essential to ensure that enough ECO subsidies go to Affordable Warmth. Providing quality information to households will also be essential to encourage take-up (Bowen and Rydge, 2011).

Concerns about the quality of the supply of home insulation may also hold back investment. Many consumers have complained about poor quality, failure to provide the most suitable form of insulation, mis-selling and difficulty to get redress. The sector is highly concentrated and consumers would gain from more competition and choice. The Office of Fair Trading has called for improving the certification process for new products, which currently hampers innovation and market entry, and for a single body being given the responsibility for monitoring the quality of insulation installations (OFT, 2012). The government should implement these recommendations without delay. A shortage of well-trained workers in insulation techniques is an additional potential bottleneck. The government is contributing to building up skills by offering up to 1000 "Green Deal" apprenticeships.

Water poverty is also an issue, with about 5 million households in England spending more than $3 \%$ of their income (after housing costs) on water and sewerage bills (HM Government, 2011a). The United Kingdom is projected to become drier in the coming decades and population rises mean demand for water to continue rising, putting pressure on water resources (Benzie et al., 2011). The water regulator, Ofwat, has set incentives for UK water providers to reduce consumption by five litres per day per property. Water providers are progressively moving from charges based on the rateable value of property to charges based on actual water consumption, which encourages more efficient water use. Currently one third of households are metered and this proportion is expected to rise to more than a half by 2015. Meters also allow addressing affordability issues, in particular through block tariff systems, in which unit tariffs rise with consumption. This allows basic water services at relatively low price to be subsidised by consumers of greater volumes of water. Even so, some low-income households unable to reduce their water use will continue to struggle to pay their bills.

WaterSure provides a safety net that caps water bills for some poor and vulnerable households which are metered. In June 2012, the Department for Environment, Food and Rural Affairs issued guidance for water suppliers to implement social tariffs that would go beyond WaterSure, which is quite narrowly targeted (DEFRA, 2012). No general affordability threshold is set, as it is presumed that social tariffs are best set by water suppliers based on local conditions. The performance of water companies in supporting consumers at risk of affordability problems will need monitoring and benchmarking to ensure effectiveness. Schemes for improving water efficiency targeted at low-income households, which yield a double social and environmental dividend, could also be considered along similar energy schemes (Walker, 2009). Finally, as for the energy sector, regulation of the water industry needs to ensure that competition and innovation lead to the delivery of good quality services at least cost to the consumer. 


\section{Public services also reduce inequality}

In-kind transfers through public services, especially health care and education, account for a higher share of government expenditure than cash transfers (Figure 9, Panel A). According to OECD estimates, including in-kind transfers into household income reduces the Gini coefficient from 0.33 to 0.25 in the United Kingdom (Figure 9, Panel B). Public services benefit every income group, but have a larger income-increasing effect in the lower part of the income distribution, as imputed income from in-kind services constitute a higher share of lower incomes than higher ones. The estimated income-increasing effects of public health care and education are respectively $44 \%$ and $25 \%$ in the bottom quintile, compared to $5 \%$ and $3 \%$ in the top quintile. Even though such estimates need to be taken with caution given difficulties in estimating the income equivalent of in-kind benefits, it is clear that public services benefit poorer households the most.

Restraint on public spending, imposed by the budget situation, could hit the poor the hardest, as they benefit relatively more from public services and have less access to alternative services than the more affluent. However, efficiency gains could compensate for lower spending. OECD studies have estimated significant scope for efficiency enhancement both in education and health care in the United Kingdom (Sutherland et al., 2007; OECD, 2010a). Better management and greater regional flexibility in public sector wages could contribute significantly. Reaping potential efficiency gains will be essential to preserve at the same time the quality of public services and fiscal sustainability.

Social housing has an important impact on lower income beneficiaries. The income-increasing effect for reduced rent tenants is $41 \%$ in the bottom quintile and $7 \%$ in the top quintile. This is the largest income-increasing effect for low-income social tenants in a sample of 21 countries for which data are available, reflecting a large social housing stock and high housing costs in the United Kingdom. Recent falls in affordable housing starts in England in a context of sharply reduced government funding and tight financial conditions are worrying. There are about 1.8 million households on waiting lists, support for private sector tenants through Local Housing Allowance is being cut and home ownership remains largely inaccessible to low-income households, even though the NewBuy scheme gives access to mortgages to first-time buyers with deposits of only 5 to $10 \%$.

The long-term solution to improving access to housing is to build more, as the government recognises (HM Government, 2011b). In that respect, monitoring the impact of the planning reform on housing supply closely to ensure that development incentives for local communities are sufficiently strong is essential. Housing policies should also ensure access to decent affordable housing or financial support for households unable to access it through the market (OECD, 2011a, Chapter 2). The number of homeless households in priority need accepted by local authorities has increased by $25 \%$ between its trough in 2009/10 and 2011/12. Even though homelessness is less than half as high as in the early 2000s, its trend should be monitored closely, as tough economic conditions combine with housing benefit cuts and limited growth of the affordable housing stock to make access to housing more difficult. Early intervention to prevent and remedy homelessness is warranted both from a social and cost-effectiveness point of view. In that respect, the strategy focusing on prevention, recently outlined by the Department for Communities and Local Government, is welcome (DCLG, 2012).

In some countries, early childhood education and care (ECEC) services have an inequalitydecreasing effect. But this is not the case in the United Kingdom, as children participation in ECEC is higher at the top than at the bottom of the income distribution (OECD, 2011c). Improving access to childcare for low income families would contribute to lowering inequality. Furthermore, as explained below, it would improve work incentives and career prospects for parents. 

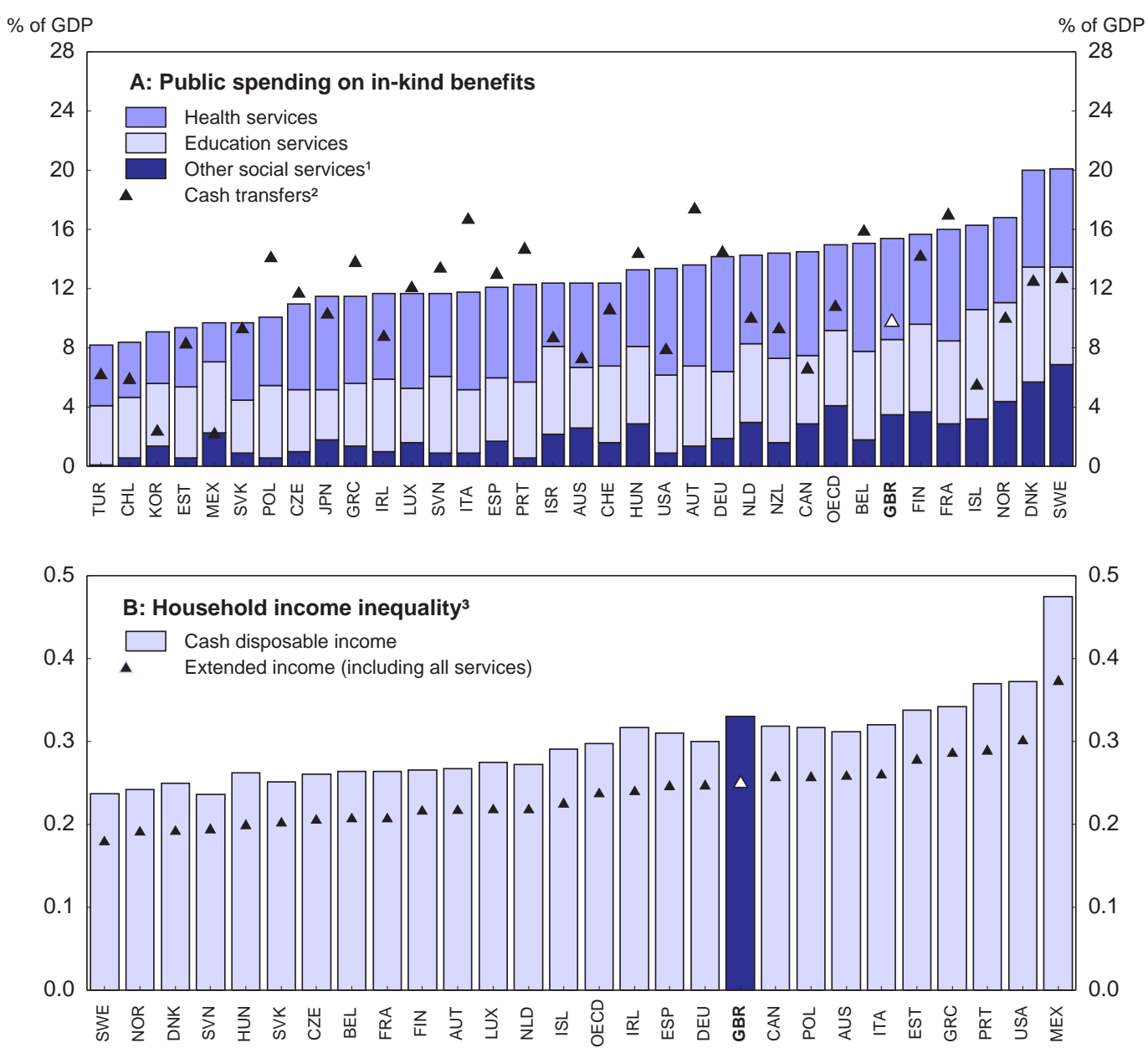

1. Other social services include services to survivors, disabled persons, unemployed, as well as those in respect of housing and social assistance (estimates of social housing are, however, not included).

2. Cash transfers to the elderly, survivors, disabled persons, families, unemployed, as well as those in respect of social assistance. Private mandatory spending, which accounts for a large share of total social spending in some countries (in particular Chile, Germany and Switzerland), is not included here.

3. Gini coefficients.

Source: OECD Social Expenditure Database, OECD Education Database and OECD (2011), Divided We Stand: Why Inequality Keeps Rising.

Redistribution via the tax and benefit system and public services play a crucial role in alleviating poverty. Nevertheless, there are limits to what redistribution can achieve. Across OECD countries, the tax and benefit system has become less effective in mitigating inequality since the mid-1990s, as governments needed to reduce benefit levels and tighten eligibility rules to contain expenditures for social protection (OECD, 2011c). Increasingly tight constraints on public finances in the current downturn have narrowed the scope for public intervention further at a time of economic hardship. While recognising that support needs to be provided to people who are unable to work, policies now increasingly focus on return to work as the best way to lift people permanently out of relative poverty.

The next section focuses on the design of welfare benefits and their impact on work incentives. But getting people into work is not enough, as low pay and short working hours increasingly result in inwork poverty (Kenway, 2008). Reducing inequality requires an improvement in the quality of jobs, which 
can be obtained by raising the skills of the workforce, especially at the lower end. Indeed, OECD (2011c) finds that up-skilling has been the only force both reducing wage dispersion and increasing employment rates since the mid-1980s in the OECD. Policies to enhance workers' skills are discussed in the last section of this paper.

\section{Welfare policies to promote employment while protecting the most vulnerable}

Social benefits attenuate inequality and provide an indispensable safety net for the most vulnerable households. However, they sometimes provide little work incentives, creating unemployment and poverty traps and long-term welfare dependency. The United Kingdom has been a leading country in the OECD in implementing welfare policies focussed on return to work (Daguerre and Etherington, 2009). Nevertheless, some individuals still face very poor work incentives, since taxes, National Insurance contributions and withdrawal of benefits would wipe out much of their gains from entering employment or working longer hours. The share of people on disability benefits is high by OECD standards, suggesting that some disability benefit recipients could return to work under appropriate conditions.

Employment rates are above the OECD average, reflecting in particular a flexible labour market, relatively small labour tax wedges and fairly low replacement rates in unemployment and retirement (Figure 10). Still, there remains a significant employment gap relative to the best performing countries, especially most Nordics, the Netherlands and Switzerland. Growth and social cohesion would benefit from pushing employment rates towards highest OECD levels. There is especially scope to raise employment rates of women - especially of child-rearing ages - and older workers. Part-time work is also much more prevalent among women than men, even if the gap is shrinking as a result of increasing involuntary parttime work due to difficult labour market conditions. Lowering childcare costs would facilitate women's employment and move towards full-time work. More personalised support and early intervention could limit further the exit of older workers from the workforce. 


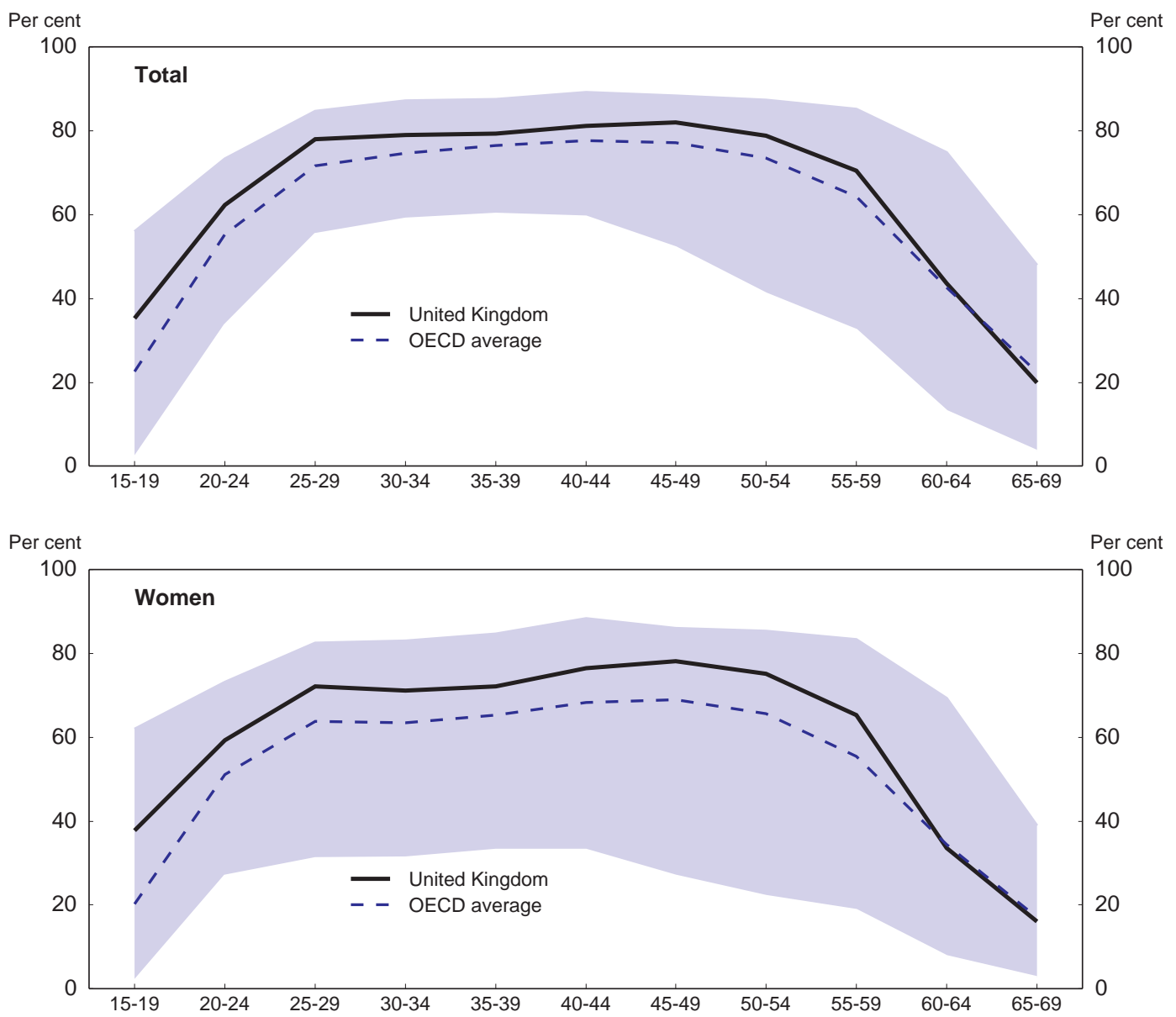

1. The shaded area shows the area between the highest and lowest employment rate for each age group over all OECD countries. Note that data for Turkey and Switzerland were not available for the cohort 65-69.

Source: OECD, Labour Force Statistics database.

This section presents the main features of the UK welfare system in an OECD perspective. It then focuses on two major reforms underway to improve work incentives and support return to work, Universal Credit and the Work Programme, which are central elements of a broader government strategy for social mobility (HM Government, 2011c) and social justice (HM Government, 2012).

\section{The welfare system provides an essential safety net}

Public cash transfers to households represent around $10 \%$ of GDP, which is slightly below the OECD average (Figure 11). The welfare system is mainly designed as a safety net for those most in need, contrasting with many systems offering more universal benefits. This accounts for the much larger share of cash transfers in continental Europe.

The Family Resources Survey (FRS) sheds light on the profile of benefit recipients and the importance of benefits in their income. About half of lone parents and about a fifth of single persons and couples with children live only on benefits. Another $15 \%$ of lone parents receive more than $50 \%$ of their income in benefits (Figure 12, Panel A). For lone parents, benefits are on average far higher than earnings (Figure 12, Panel B). Overall, the welfare system protects a sizeable share of the population, notably lone 
parents and families with children. This safety net is essential, but poor work incentives may trap some households into relative poverty. The introduction of Universal Credit aims at tackling this issue, but work incentives in core recipient groups, especially facing high childcare costs, need to be enhanced.

\section{Figure 11. Public cash transfers ${ }^{1}$}

2007

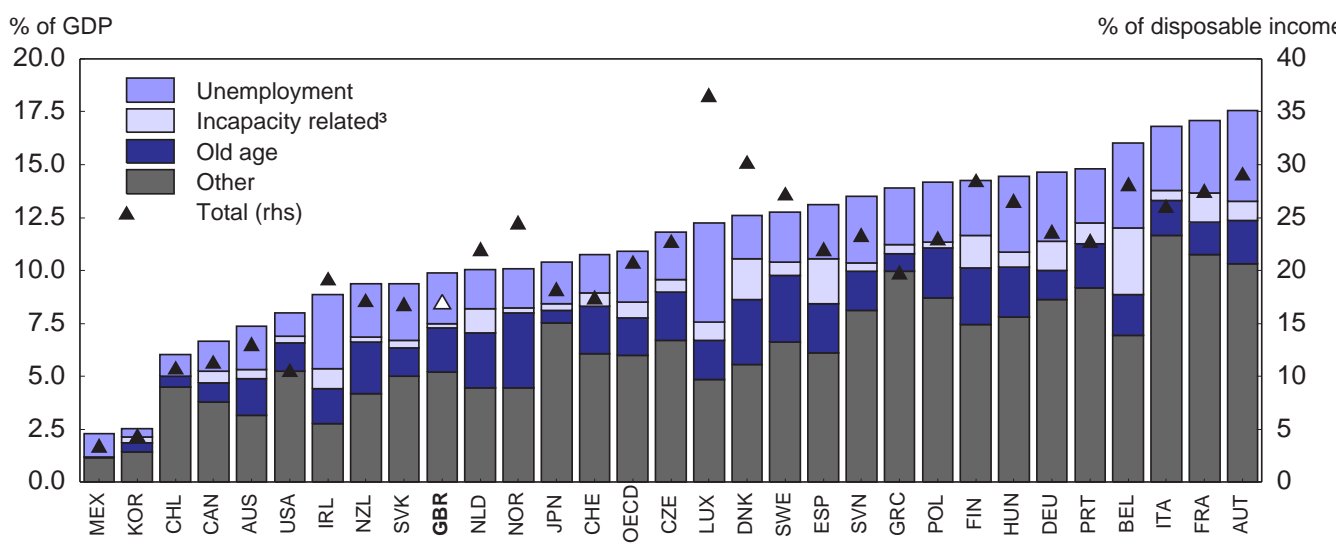

1. The data shown here exclude private mandatory spending which accounts for an important share of total social spending in some countries (in particular Chile, Germany and Switzerland). In addition, public cash transfers shown here may not fully account for those programmes and services provided, or co-financed, by local governments. Measurement gaps may be high, notably in federal countries such as Canada.

2. Refers to net household disposable income.

3. Incapacity-related spending covers expenditure on disability pensions and sick leave schemes (occupational injury and other sickness daily allowances).

Source: OECD Social Expenditure Database.

Figure 12. Benefit dependency by family type ${ }^{1}$

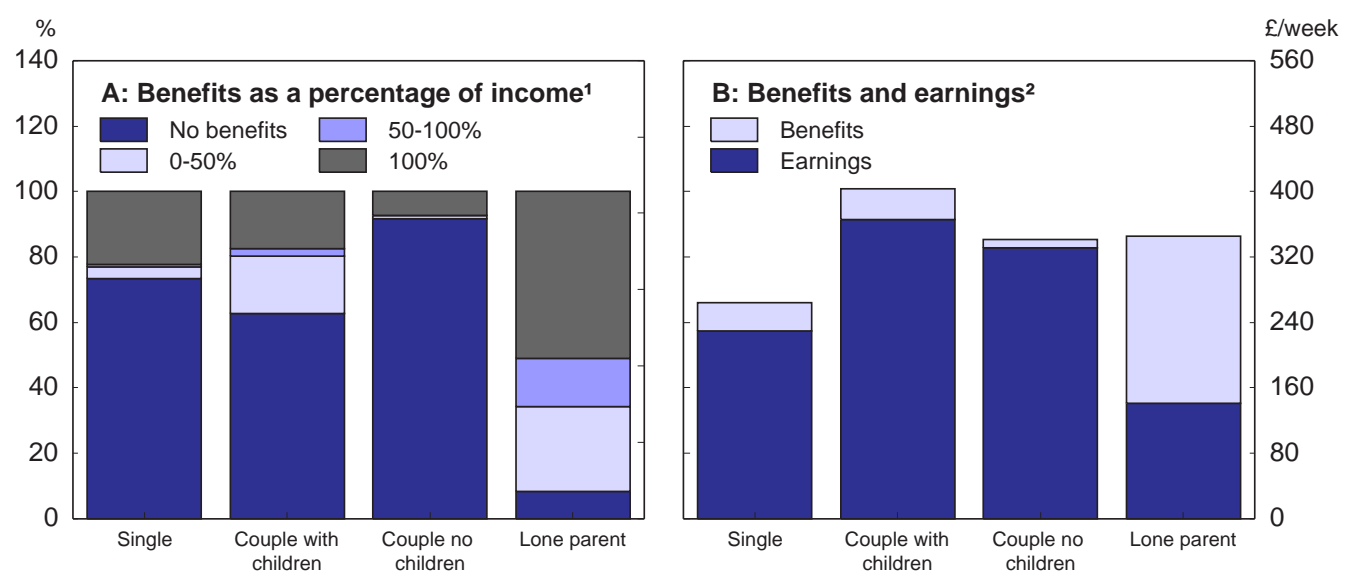

1. Refers to gross disposable income.

2. Per adult in the household.

Source: Family Resources Survey and OECD calculations.

\section{Universal credit is expected to improve work incentives}

The Welfare Reform Act 2012 introduces a wide range of reforms to the benefit and tax credit system (Universal Credit). Under the current system a working-age individual with low earnings and no disabilities may be entitled to receive payments from one or more of three main benefit groups; unemployment benefits and social assistance; the Housing Benefit and Council Tax Benefit and Tax 
Credits. Different benefits within each of these three groups are internally coordinated and roughly based on the same framework, while there is close to no coordination across the three benefit groups, leading to a rather erratic incentive structure. Under Universal Credit, the main means-tested benefits, except the Council Tax Benefit, will be pooled into one single benefit with generous earnings disregards and one single rate of benefit withdrawal against income (taper rate). At the same time, support for childcare through the benefit system is made accessible for parents regardless of how many hours a week they work (Pareliussen, 2013). Stated goals of the Universal Credit reform include giving people incentives to work, diminishing complexity, reducing relative poverty and containing the rising cost of welfare dependency (DWP, 2010a).

Universal Credit will give better incentives to work than the current system. The highest Marginal Effective Tax Rate (METR), the amount which will be lost in taxes and loss of benefits from earning an additional pound, will be $76.2 \%$ after the reform. Although still high in absolute terms, this is lower than in the existing system, where the METR could reach $100 \%$. Incentives to work, as measured by effective tax rates, will also be better than the OECD average for most individuals after the reform (Pareliussen, 2013). Further reducing METRs by reducing the taper rate would increase spending on benefits unless the overall level of benefits is lowered at the same time.

The reform represents a radical overhaul of the incentive structure compared to the existing system, and is in many ways a big leap into uncharted territory. It is therefore impossible to say with certainty to what extent the Universal Credit will contribute to reducing welfare dependency and hence increase the growth potential of the economy and lower the cost of the welfare system in the future. This depends on how changes in incentives induce behavioural change.

Although impact analyses rest on a number of assumptions, the conclusion that labour supply will increase as a result of the reform seems robust. The Department for Work and Pensions (DWP) assumed that the net effect on labour supply will reduce the number of workless households by 300000 (DWP, 2010a). This number is very sensitive to assumptions regarding labour supply elasticities, potential wages and work hours especially for inactive lone parents and second earners with children. OECD analysis based on different sets of assumptions (Pareliussen, 2013) estimates a reduction of the number of workless households could be between 45000 and 240000 , and an increase in labour supply equivalent to 15000 to 85000 full-time employees. Childcare costs are not taken into account in either of these analyses. Unless the disincentive of high childcare costs is reduced, the positive effect on labour supply is likely to be lower.

Universal Credit also represents an indisputable simplification of the benefit system, which in the long run will most likely reduce administrative costs and the potential for fraud and error. The increased simplicity for users will also increase the flexibility of the labour force, since the uncertainty of having to re-apply for benefits after a period of work represents an additional cost of entering work in the current system. On the other hand, necessary steps should be taken to ensure support to users who do not have access to services online, and to users who face challenges when going from weekly to monthly budgeting (Finn and Tarr, 2012). 
Households in the bottom half of the earnings distribution will on average be better off after the reform, while those in the upper half will be marginally worse off (DWP, 2011). Take-up of benefits will increase after reform, since households who are today taking up only part of the benefits are eligible to will automatically receive their full entitlement under Universal Credit. The integrated nature of the reform will also remove the need for separate applications when moving from one benefit to another and when moving in and out of work, as the separation between out-of-work and in-work benefits is removed.

The Department of Work and Pensions estimates that some $£ 6.9$ billion to $£ 12.7$ billion worth of benefits went unclaimed compared to a total of $£ 38.1$ billion claimed in 2008-09. This represents a take-up rate in the range of 75 to $85 \%$ (DWP, 2010b). The combined impact of take-up and increased entitlements for low income families will have a further positive impact in reducing poverty and increasing equality. These aspects of the reform are expected to lift around 900000 individuals, including 350000 children, out of relative poverty (DWP, 2011). This improvement will, however, be more than offset by cuts to the benefit system introduced since the 2010 Spending Review, such as cuts to the Housing Benefit and changes in indexation of benefits (Brewer et al., 2012; HM Treasury, 2012).

The major gainers of the introduction of the Universal Credit are primary earners in couples (Figure 13, Panel A and B), which will have both better marginal work incentives and higher income after the reform. Many lone parents will face better work incentives and higher income (Figure 14, Panels A and B). While the effect of the reform for second earners will depend on individual circumstances (Figure 14, Panel C and D), household income will also increase for this group. For single-persons the effect of the reform is ambiguous.

Figure 13. Incentives to work for a primary earner in a couple with children ${ }^{1}$
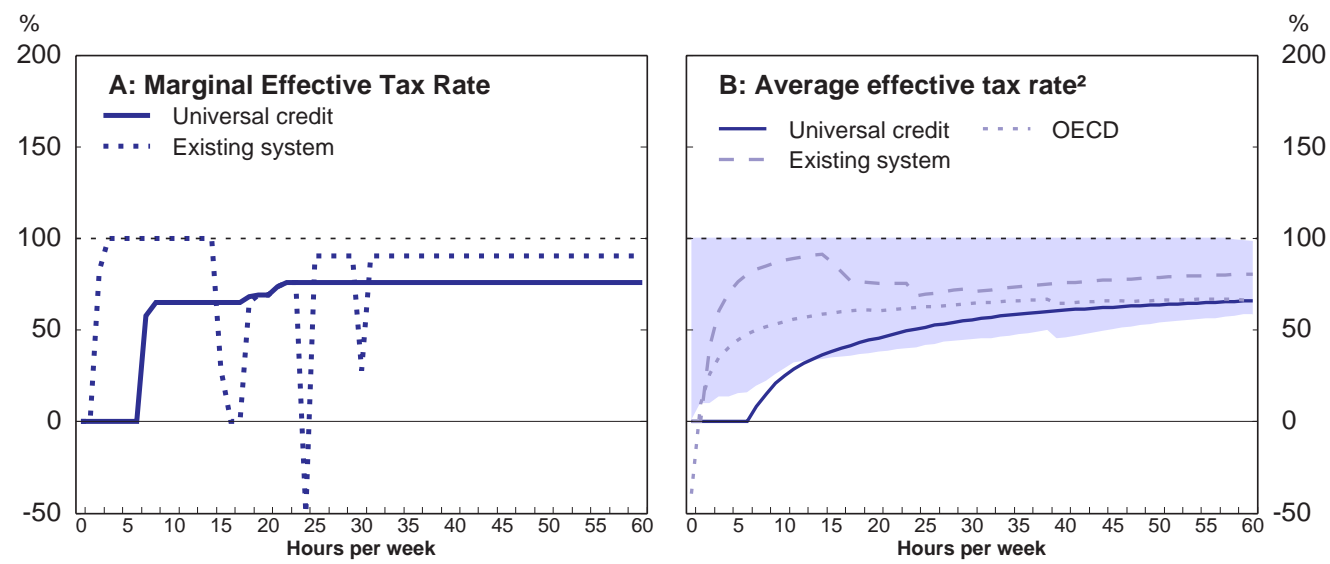

1. Earning $50 \%$ of average hourly wage. Extreme negative marginal effective tax rates have been capped at $-50 \%$. The full set of model assumptions can be found in Pareliussen (2013).

2. Data for the OECD refer to 2010 . The shaded area denotes the range between the 25 th and the 75 th percentile in the OECD area.

Source: OECD calculations and OECD Taxben model. 
Figure 14. Incentives to work for lone parents and second earners ${ }^{1}$

Marginal effective tax rates
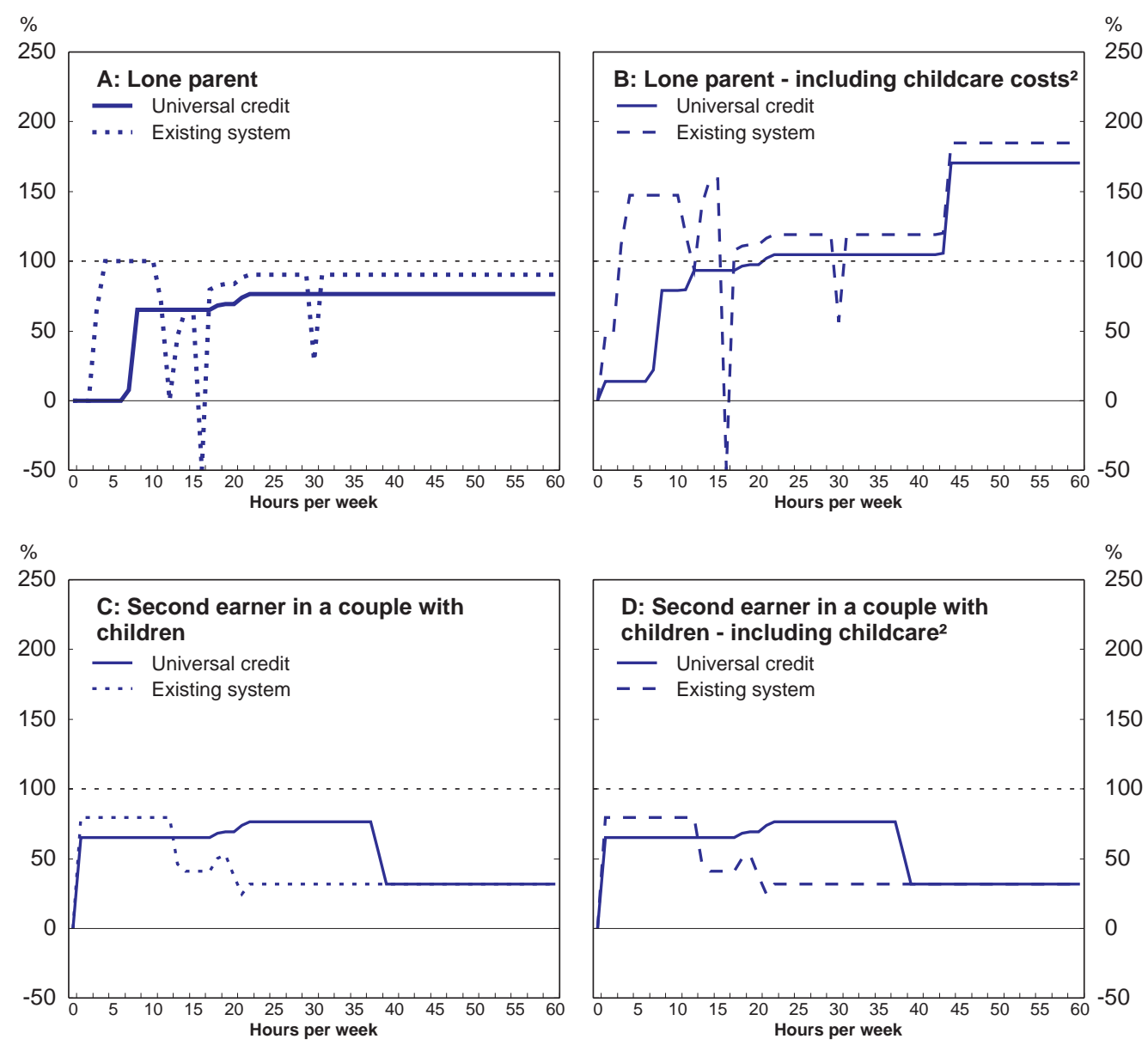

1. Earning $50 \%$ of average hourly wage. Extreme negative marginal effective tax rates have been capped at $-50 \%$. The full set of model assumptions can be found in Pareliussen (2013).

2. Assuming childcare costs of $£ 4$ per child per hour worked.

Source: OECD calculations.

The removal of the current 16-hour threshold to become eligible for childcare support in combination with the increased earnings disregards will give significantly better incentives for lone parents to work a few hours a week compared to the current system (Figure 14, Panel B). The removal of the threshold for childcare support is also positive for second earners, as the very high METRs below the 16hour threshold in the current system are lowered considerably (Figure 14, Panel D). Still, high childcare costs can reduce the gain of the reform especially for low- to medium-wage second earners and lone parents earning more than their earnings disregard. These groups respond particularly well to improved incentives (OECD, 2011e). In addition lone parents are over-represented in poor households, so improving lone parent's incentives to work would have the potential to reduce relative poverty and child poverty even further than the reform as it stands today.

In this area, the reform could be improved by a number of measures, although potential gains should be weighed against significant fiscal costs. Measures include increasing the refund rate for childcare, reducing the taper rate for those who receive childcare support and/or introducing a dedicated disregard for second earners in couples. The most targeted way of addressing work incentives affected by 
childcare costs would be to increase the refund rate for eligible childcare costs. Potential cost-driving effects on childcare provision should be considered. The rate was lowered from $80 \%$ to $70 \%$ in the 2010 spending review, with estimated savings of $£ 350$ million a year. In comparison, reducing the overall taper rate from 65 to $60 \%$ would cost approximately $£ 1300$ million a year. On the other hand, better incentives for lone parents and second earners with children would increase the effectiveness of the reform and thereby increase the economic growth potential and reduce inequality. These costs could be partly offset by reducing the disregard, especially for primary earners in couples.

Reforms outside of the scope of Universal Credit could also be helpful in improving incentives for those dependent on formal childcare. Childcare fees, the gross amounts charged to parents regardless of the subsidy that providers may receive from public authorities or private donations, for a two-year old attending accredited early-years care and education services amount to $25 \%$ of the average wage in the United Kingdom, compared to $8 \%$ in Finland and 5\% in Sweden (OECD, 2007b). This is partially explained by higher levels of provider subsidies in these Nordic countries. Net childcare costs, after deduction of cash benefits, rebates and tax concessions, vary with households characteristics, but also account for a substantially higher share of income in the United Kingdom than in Finland and Sweden. Thus, it often does not pay for both parents to hold full-time jobs. Although a large share of early years care is free, provided by the formal or informal sectors, the fact that nursery schools are often half-day raises the need for some parents to resort to private day care and take time off to transport children from one care source to another. One parent working full-time and the other part-time is the norm in the United Kingdom. The OECD has earlier suggested that childcare support needs to be provided in a more coherent way (OECD, 2005a). In this respect, the launch of a commission on childcare in June 2012 to look at how to reduce the costs of childcare for working families and the regulatory burdens on childcare providers is welcome.

The government has announced some steps to increase flexibility and to offer 15 hours of free nursery school to the $40 \%$ least advantaged 2 -year olds, which in addition to improving work incentives, could have positive effects on child development and inequality. Extending the current 15 hours a week free childcare in nursery schools for 3- and 4-year olds to younger children and increasing the user flexibility of this scheme would lower childcare costs to parents and ensure that parents could make effective use of the childcare which is provided.

The Council Tax Benefit today has approximately 5.8 million claimants and represents $2.5 \%$ of total public expenditure on benefits (Jin et. al. 2010). The government has issued guidance setting out a framework that local authorities can use to run schemes that are consistent with the design of Universal Credit. While local authorities have an incentive to promote work, as it reduces expenditure on local council tax support schemes, measures such as these are needed to ensure that the decision to localise the benefit does not undermine the improvements in work incentives brought by the Universal Credit.

The simplicity and transparency of Universal Credit combined with better work incentives for many individuals, is a step forward. It should make it easier for people to understand that work pays. Universal Credit will furthermore provide individuals with a seamless route to enter, exit and re-enter work without running the risk of losing their entitlement. Although the marginal tax rates still remain relatively high, combined with an effective conditionality regime, the Universal Credit reform can change social attitudes to work in the long run. If the remaining weaknesses would be addressed, the gain from the reform in terms of making work pay and reducing poverty would be even bigger.

Universal Credit, as any other major system change, faces the risk of implementation problems. Universal Credit depends on real time information on income, which is to be achieved through HM Revenue and Customs Real Time Information (RTI) project. System failure in the RTI could lead to unnecessary uncertainties and hardship for vulnerable groups in the transition period, especially if 
Universal Credit recipients were not receiving timely and correct payments. The planned phased introduction of Universal Credit is helpful in mitigating these risks, and should be combined with sound contingency plans and transparent information for users (Finn and Tarr, 2012).

\section{The Work Programme is a significant step forward, but activation policies are facing a tough challenge}

Well-designed active labour market policies (ALMPs), including job placement services, subsidised employment and training can play a major role in helping unemployed people back to work. Recent research examining a large number of ALMP programmes in a large sample of OECD and nonOECD countries suggests that job search assistance combined with sanctions for non-compliance with programme requirements and subsidised employment in the private sector can be effective in increasing participants' employment prospects. Public sector employment programmes are generally less effective, although the United Kingdom's Future Jobs Fund, a largely public and voluntary sector employment programme, shows a positive impact on unsubsidised employment (DWP, 2012). Training programmes seem to have little short-term impact, but yield better medium-term results. They are more effective when unemployment is high, perhaps because of the participation of people with higher qualifications. Training programmes targeted at young people seem less effective than programmes opened to wider groups, presumably because they include more people with labour market disadvantage. However, the design of training programmes is bound to have a great influence on their outcomes, as discussed in the next section (Card et al., 2010; Kluve, 2010).

ALMP programmes are especially important at times when the economy is undergoing deep structural change and labour needs to be reallocated across economic sectors, implying more difficult human resources management and often retraining of workers. The current period of rebalancing of the UK economy, as in many other OECD countries, imposes a tough challenge on ALMPs. The United Kingdom has been at the vanguard of labour market strategies focussing on quick re-entry into the labour market, entailing strict conditionality regimes and mutual obligations between benefit claimants and public employment services. Only Australia and some US states seem to have gone further in moving people from benefits to work (Daguerre and Etherington, 2009). Eligibility criteria for unemployment benefits are among the strictest in the OECD, although somewhat lighter than in some southern and eastern Europe countries, where entitlement conditions are more restrictive and sanctions for refusing a job or an active labour market programme are tougher (Figure 15, Panel A).

Conditionality will be strengthened and sanctions will be tougher under Universal Credit. Monitoring of job search is among the strictest in the OECD, with a fortnightly job-search review. Welldesigned ALMPs have been one of the driving forces behind the overall high UK employment rate (OECD, 2005b; RWI Essen, 2005). Nevertheless, some population groups still face substantial difficulties in accessing work, hampering their ability to improve their living conditions. This is particularly the case of disability benefit recipients and young people with low qualifications.

About $7 \%$ of the population aged 20-64 receives disability benefits, above the OECD average of less than $6 \%$, albeit below the proportion in Nordic countries, where disability benefits tend to be more generous (Figure 15, Panel B). The share of people on disability benefits rose sharply between the early 1980 s and the mid-1990s, partly through moves from unemployment to disability. It subsequently stabilised, as a result of falling unemployment, enhanced support for return to work and tightening of eligibility conditions. It has been declining somewhat since the mid-2000s, but remains high in international comparison, which suggests there is scope to bring it down further (OECD, 2010b). 
Figure 15. Eligibility to unemployment benefits and disability benefits recipiency ${ }^{1}$
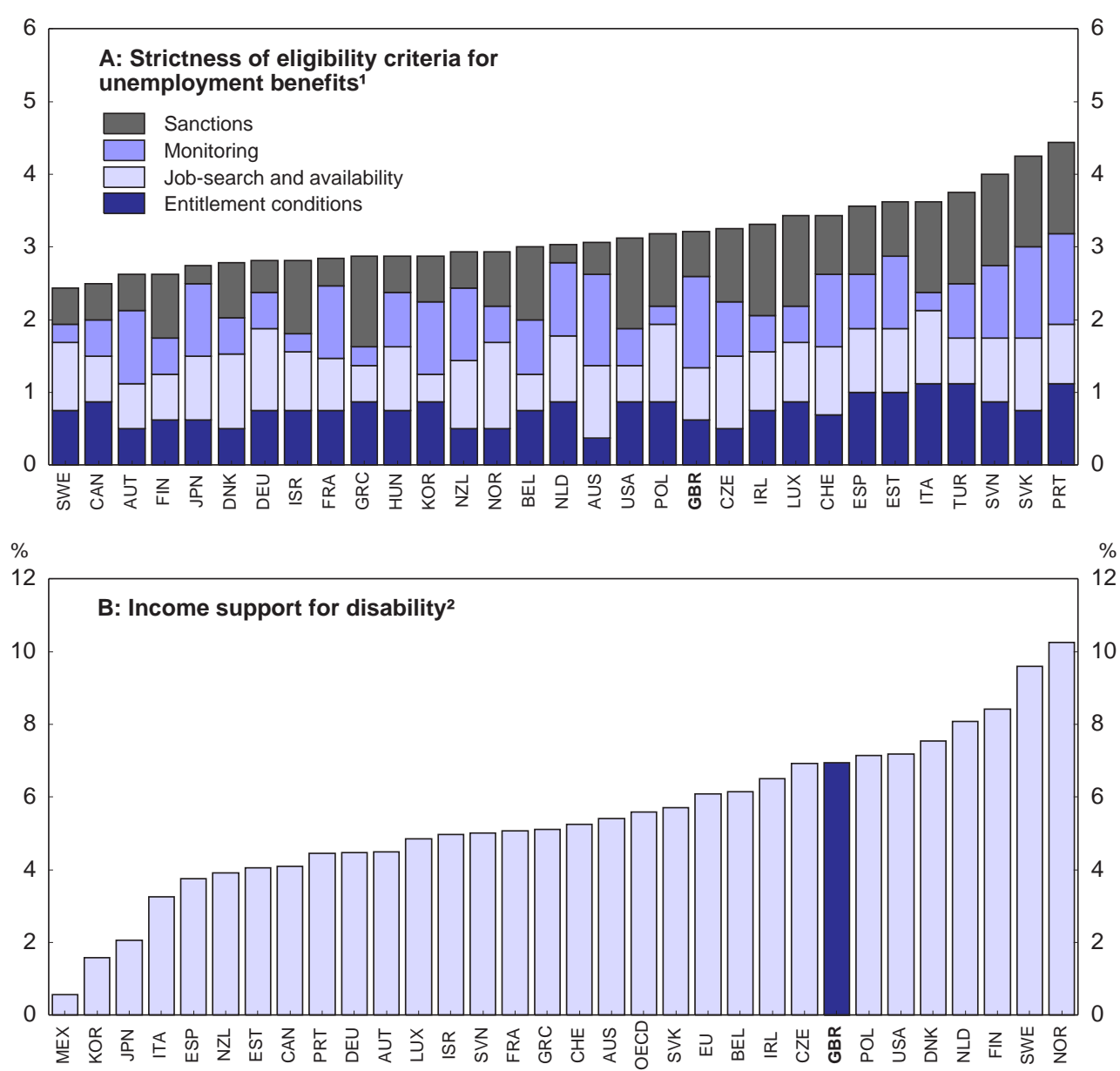

1. Scores range from 1 (least strict) to 5 (most strict).

2. Refers to the percentage of the population aged 20-64 years old receiving disability benefits. Disability benefits include benefits received from schemes to which beneficiaries have paid contributions (contributory), programmes financed by general taxation (non-contributory) and work injury schemes. Data refer to 2009, except for: Luxembourg (2005); Canada, France, Italy, Spain and Poland (2007); Australia, Austria, Belgium, United Kingdom, Greece, Ireland, Japan, Korea, Slovenia (2008) and for Denmark, Estonia, Hungary, Israel and Portugal (2010).

Source: OECD (2012), Economic Policy Reforms 2012: Going for Growth; Venn, D. (2012), Eligibility Criteria for Unemployment Benefits: Quantitative Indicators for OECD and EU Countries, OECD.

The government launched the Work Programme in June 2011 to help the unemployed in need of tailored support, such as disability benefit claimants and long-term unemployed, to undertake active and effective job-search. The two cornerstones of the programme are personalised support and payment for results. Emphasis on personalised support and early intervention is supported by international evidence (OECD, 2005b; Daguerre and Etherington, 2009). The Work Programme gives providers more freedom to personalise support than previous welfare-to-work schemes, allowing more innovative approaches. Service providers, which include private, public and voluntary sector organisations, face clear incentives to deliver sustained job outcomes for participants, as a significant part of their remuneration comes from delayed payments, received for up to two years conditional on the participant remaining in work. Furthermore, helping customers with lower job prospects results in additional payments, mitigating incentives for creamskimming. 
While the Work Programme is based on sound principles, anecdotal evidence suggests some implementations problems, including concerns about financial viability for service providers in the current challenging labour market conditions and coordination problems between private firms and voluntary organisations, which have led a number of charities to withdraw from the programme. To ensure the Work Programme is efficiently addressing its objectives, the government has commissioned an independent evaluation by the IES (Institute for Employment Studies).

About half of the five million people receiving out-of-work benefits are on disability benefits and it is likely that some could go back to work under appropriate conditions. The Work Capability Assessment (WCA) was introduced in October 2008 to assess the condition of people on Employment and Support Allowance, which provides financial support for those unable to work because of illness or disability. Reassessing existing claimants according to new criteria is exceptional in an OECD context (OECD, 2010b). The WCA has been very controversial. The British Medical Association called for scrapping the scheme. Roughly $40 \%$ of people found fit for work appeal the decision and around $38 \%$ of those people who appeal have the decision overturned. Overall, $15 \%$ of fit for work decisions are overturned on appeal.

The first Independent Review of the WCA (Harrington, 2010) and the Work and Pensions Committee report on incapacity benefit reassessment (2011) both criticised how the WCA was working in practice. The second Independent Review of the WCA (Harrington, 2011) found that improvements had been made, but also that more needs to be done. The WCA needs further improvement to make it fairer and more effective. Many people currently on benefits could gain from going back to work under appropriate conditions. However, being fit for work is often perceived as "failing" the assessment (Harrington, 2011). To remedy this situation, better communication about the aims of the programme is needed. Furthermore, it is crucial to give strong support to people assessed as fit for work in their search for a job. Therefore, cooperation between WCA decision makers and service providers in the Work Programme needs to be intensified.

More than one third of new disability benefit claimants in 2009 were suffering from mental health problems and this proportion was even exceeding $40 \%$ in the 20-34 age group. This is not unique to the United Kingdom, as mental health problems are gradually becoming the main cause for disability claims across OECD countries, accounting on average for a third of the total and often more than half for young people (OECD, 2012b). According to an evaluation for the OECD Mental Health and Work project (OECD, 2013), the United Kingdom is among the most advanced countries in terms of awareness about the costs of mental illness for employers and society as a whole, and of the mental-health benefits of employment. Integration of health and employment services is also well developed, as illustrated by the Improving Access to Psychological Therapies (IAPT) initiative which aims to provide access to both evidence-based psychological therapies and matching employment services.

However, the benefit system lacks focus on early intervention, which could prevent more people from needlessly moving into benefits and support quick return to work. At present, support for return to work would typically only come after 9 to 12 months on sick leave. Fit-for-Work Service (FFWS) pilots provide employees in the early stages of sickness absence (normally 4-12 weeks of absence) with casemanaged multidisciplinary support to enable a quick return-to-work. The results of the pilots are encouraging and this type of early intervention should be expanded further. Health care professionals' role in helping return to work should be enhanced by the diffusion of evidence-based guidelines and closer monitoring of the use of the "fit note", which should include an assessment of capability to work in other activities for people no longer able to carry on their previous activity.

As recommended by the Independent Review of Sickness Absence (Black and Frost, 2011), an independent in-depth physical and/or mental health assessment of individuals on sick leave should take place after a few weeks of absence, to advise on needs for rehabilitation and support for return to work. In 
addition, the capacity of public employment services to identify psychological problems through adequate screening tools, provide psychological services and refer people in need to health services in a timely manner should be developed. Employers should also be encouraged to play a greater role in the prevention of work-related diseases and the rehabilitation of workers, whether through occupational health regulations or incentives, such as the tax relief for expenditure by employers to keep sick employees in work proposed by the Independent Review of Sickness Absence.

\section{Skill deficiencies are also holding back employment and fostering inequality}

\section{Low education achievements penalise children from lower socio-economic backgrounds}

Tackling youth unemployment is a major challenge, with both short term and longer term social and economic implications. Young people must be prevented from falling into relative poverty and social exclusion, which would likely lead to permanent effects on their working careers. The government has appropriately taken measures focussed on giving young people the skills and opportunities to gain longterm employment in the private sector. The Youth Contract is designed to provide 18-24 year-olds with nearly half a million new opportunities, in the form of apprenticeships and work experience placements. Subsidies will encourage businesses to recruit young people and offer apprenticeships. Evaluations of private sector subsidised employment programmes in other OECD countries have frequently found a positive impact on employment (OECD, 2005b). Nevertheless, the impact of the Youth Contract on sustained employment of young people will need to be monitored closely.

People with low education levels are most at risk of unemployment. Education premia for people with tertiary education in the United Kingdom are among the highest in the OECD, while pay penalties affecting individuals without basic qualifications are larger than the OECD average (Figure 16 and OECD, 2011d). Skill deficiency during adulthood is the obvious outcome of poor performances at school. According to PISA data, the impact of parental background on young people's cognitive skills varies substantially across countries. In France, New Zealand, the United States and the United Kingdom, the socio-economic background has the strongest influence on education achievements (Causa and Chapuis, 2009). Given that a strong intergenerational persistence in schooling achievements has important consequences for equality and social mobility, skill development and more equal opportunities through the education system are of crucial importance.

The government has taken steps to reform the education system, which are consistent with the recommendations from the 2011 OECD Economic Survey of the United Kingdom (OECD, 2011a) outlined in Box 3. The focus on disadvantaged children is being reinforced through the statutory entitlement to 15 hours per week of free early education for disadvantaged two year olds, which will be introduced in two phases, starting in September 2013. The monitoring of the Pupil Premium, which is allocated to schools to work with pupils who have been registered for free school meals at any point in the last six years, is being improved by introducing a requirement that schools report to parents on how they have used the Premium and by including in the performance tables separate results for the attainment of pupils eligible for the Premium. The government has been reviewing A-levels, giving universities a much greater role in reforming the qualifications, which should address the problem of grade inflation witnessed over recent years (OECD, 2011a). 
ECO/WKP(2013)26

Figure 16. Relative earnings from employment by level of educational attainment ${ }^{1}$ Upper secondary and post-secondary non-tertiary education $=100$

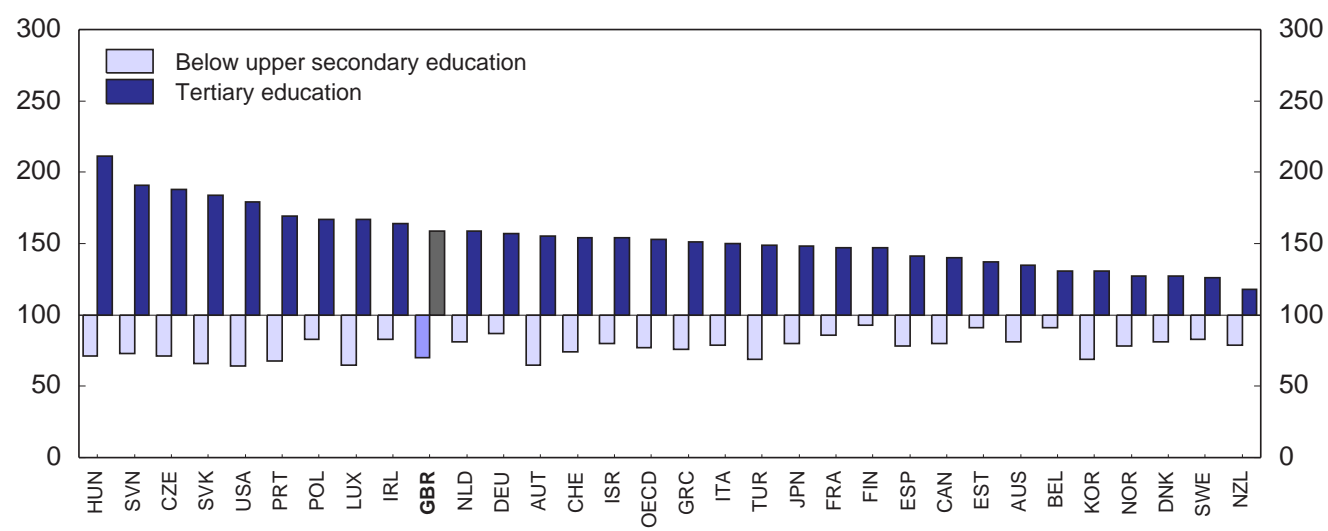

1. Refers to $25-64$ year-olds. Data for 2009 or latest available year.

Source: OECD (2011), Education at a Glance 2011.

\section{Box 3. Improving educational outcomes and raising skills}

Education and human capital are crucial drivers of employment, output growth and well-being. Better educational performance improves labour market outcomes, enhances workers' productivity, reduces income inequalities and promotes intergenerational mobility and social cohesion. It contributes to higher life satisfaction through better employment, income and social relations (OECD, 2011a). In the United Kingdom, wide gaps in education and skills and a low level of intergenerational mobility generate large inequalities relative to many other OECD countries. Over the past decade, several reforms have aimed at tackling income inequalities through the improvement of educational attainment and social mobility. Nevertheless, the scope for deeper skill accumulation and more equal opportunities remains substantial. This box discusses current issues and potential interventions to raise skill levels among the population and especially the most disadvantaged social groups.

The provision of high-quality pre-schooling delivers high private and public economic returns, especially for children from disadvantaged backgrounds. Indeed, a lack of skills or access to credit for the creation of a nurturing environment at home, and little awareness of the returns to education may lead to under-investment in schooling. Yet, cognitive and non-cognitive skill accumulation during early childhood is crucial for later skill formation (Cuhna and Heckman, 2010; Chowdry et al., 2010). Programmes such as the Sure Start Children's Centres and the Early Years entitlement expanded pre-schooling since the beginning of the $2000 \mathrm{~s}$, leading to an enrolment rate of $95 \%$ for 3 to 4 year-old children (well above the OECD average of $72 \%$ ). Impact evaluations of the programmes are blurred. Despite some recent evidence of behavioural and health benefits, assessments on cognitive skills indicate minor effects (Merrell et al., 2007). Furthermore, the impact of parents' income on children educational performances has been worsening in recent years. Given the broader effect of pre-schooling on disadvantaged children (Hopkins et al., 2010; Goodman and Sianesi, 2005), resources should be geared towards deprived families, which should also be the target of wider outreach activities and, possibly, of child/parent home support in the neediest cases.

The relationship between spending on education and schooling performances has proven to be weak at the international level and in many OECD countries (Sutherland et al., 2009; OECD, 2007c). Despite a real spending per pupil increase of $4.8 \%$ annually between 1997 and 2010, assessments of cognitive improvements are mixed. Unlike national indicators, international data report a sharp fall in the productivity of education for the United Kingdom. Estimates by Sutherland et al. (2007) suggest that moving the primary and secondary school systems to the OECD best-practice would allow delivering current output using $20 \%$ less resources. Firstly, given the relevance of quality teaching for schooling achievements (Hanushek and Wossman, 2007; Slater et al., 2009), recruiting and retaining better teachers should be a priority. Individual schools should be provided with tools and incentives to hire, reward and replace teachers according to their performance. Extending these practices to Local Authority maintained schools could also increase their competitiveness relative to independent schools, academies, faith schools and Free Schools. Indeed, although the spreading of alternative school arrangements widens the scope of users' choice, it may exacerbate the correlation between socio-economic backgrounds and school resources and quality. Teaching practices could be also improved by reducing the extensive reliance of the system on test scores, and rather develop more comprehensive indicators of school performance. Indeed, despite being important, benchmarking is deemed to have incentivised grades inflation, "teaching to tests" and scarce attention to the development of non-cognitive skills. 
The impact of the socio-economic background on PISA scores is higher in the United Kingdom than in most OECD countries (OECD, 2011d; Causa and Chapuis, 2009), suggesting that skill accumulation might not be adequate for a large share of the population exiting compulsory schooling, with adverse consequences on drop-out rates, labour market opportunities and income inequality. Exceptionally wide skill differentials and high income and education persistence across generations mirror the poor functioning of deprivation funding in the United Kingdom. Indeed, the complexity of the system is deemed responsible for low levels of pass-through of governmental funding from local authorities to schools, which tend to face low incentives to spend on and retain disadvantaged students. By making the system smoother and introducing a pupil premium, the government has started to address these issues. However, solving underlying incentive problems would require that the pupil premium increases and becomes the only means of deprivation funding, since the current system of transfers from local authorities to schools lacks transparency and proper targeting of pupils in need. Additionally, school spending for disadvantaged children could be incentivised through improved user choice. Needy families living in areas with low-quality oversubscribed schools have often limited or no alternatives. Preventing the use of residence-based criteria for admission and encouraging the entry of new schools would be warranted as recommended in the OECD Economic Survey of the United Kingdom 2011 (OECD, 2011a).

Participation rates in non-compulsory education have been increasing in recent years, but cross-country comparisons reveal that they are still low. The number of young people neither in education nor in employment or training (NEETs) has swelled during the recession and is among the highest in the OECD. The government's commitment to raise the compulsory participation age to 17 in 2013 and 18 in 2015 will increase participation in education and training. What is most important, though, is that students are equipped with the adequate skills to enter the labour market. Available evidence suggests that some vocational training has a low or even negative impact on future returns (Machin and Vignoles, 2006), with the exception of some high-quality apprenticeships. Reducing the complexity of the system and the fragmentation of the programmes, while increasing the quality and the number of available positions, may enhance the attractiveness of vocational training, having a positive impact on labour market outcomes and productivity.

Tertiary education attainment levels are in line with the OECD average. The outstanding quality of universities and the above-average returns to tertiary schooling have spurred participation in recent years. Nonetheless, little evidence of falling returns over time suggests that demand for the highly skilled has kept the pace of supply (Walker and Zhu, 2008). Increasing the available positions, while maintaining high standards of quality, would promote human capital accumulation, economic growth, equality and social mobility. Furthermore, high private returns justify recent reforms making students bear a larger share of the costs. In such a way, savings from lower public funding could be used to expand available positions, especially in those fields with higher social and private returns. At the same time, however, government interventions should provide support to the neediest, who are currently underrepresented among graduates and whose access to tertiary education might be further discouraged by higher fees.

1. This Box is largely based on Chapter 3 of the 2011 OECD Economic Survey of the United Kingdom (OECD, 2011a).

\section{Transition from education to work can prove challenging}

Young people undertaking the complex process of transition from education to work do not always approach the labour market with the appropriate skills and qualifications. Although the UK Commission's Employer Skills Survey 2011 (UKCES, 2011b) reveals that most of the employers who recruited education leavers found them adequately prepared for work, a significant minority was not satisfied with their work-readiness, mentioning lack of experience and motivation as the overwhelming reasons. The survey also reveals the existence of pockets of skill deficiency, notably among skilled trade occupations, where a third of all vacancies are classified as "hard-to-fill". This evidence suggests that increasing opportunities for young people to gain experience would be beneficial.

Encouraging a proper combination of study and work may smooth the transition to work, avoid high drop-out levels, open up greater prospects at the time of full integration in the labour market, as well as enhance performances of workers in the long run. In this respect, student jobs, internships and apprenticeships could be crucial in pulling the youth out of the vicious circle "no job without experience; no experience without job". While on-the-job training would allow young people to compensate for gaps in school education, a forward-looking perspective to raise skills would also warrant the predisposition of 
second-chance schools, through which drop-outs could resume education and gain qualifications buttressing their employability. England has launched a programme of education and training guarantees until the age of 19, built on a closer co-operation between schools, training providers and employment stakeholders (OECD, 2010c). Connection services, which are in charge of providing assistance to young people, collect and transmit information on school leavers, training and placement, basically serving as a job brokerage service that ensures awareness of employment opportunities among young people.

\section{Vocational training needs to be strengthened and cooperation with employers reinforced}

The current UK skills strategy aims at improving the level of workplace skills through the support of vocational education and training (VET) and apprenticeship programmes. Although England and Wales are strongly committed to achieving the skill targets set out in the Leitch review (HM Treasury, 2006) and have made available substantial resources to this aim, the degree of business involvement in VET and the provision of work-related training are low and often declining (UKCES, 2012).

As a crucial step towards the up-skilling of the workforce, employer engagement should be clearly encouraged. Employers' engagement in policy design and delivery is much stronger in Austria, Germany, Norway and Switzerland (Hoeckel et al., 2009), which feature essentially dual systems in which employers cover on-the-job training, while the state funds off-the-job training and education. These countries have developed systems of effective co-operation and checks and balances among social partners that ensure successful policy implementation and effectiveness. Employers are in the best position to evaluate whether the contents of VET programmes respond appropriately to labour market requirements, and therefore to provide advice for policy development. At the same time the involvement of business makes them understand better the institutional system and respond more broadly to governmental initiatives.

While past initiatives have been strongly targeted at the public sector, efforts should now be geared towards the private sector and small and medium sized enterprises in particular. In April 2012 the Youth Contract was launched, offering nearly half a million 18-24 year olds new work opportunities, such as apprenticeships and other work experience. Within the $£ 1$ billion package, a wage incentive one-off payment worth up to $£ 2275$ per person will be granted to employers who recruit young people from the Work Programme or Jobcentre plus over the next three years. Additional financial and operational aid will be provided to those employing young people with disabilities.

As regards apprenticeships, on top of covering training costs, the National Apprenticeship Service will make $£ 1500$ grants available to small and medium sized employers hiring their first 1624 year old apprentices. By raising employers' incentives and involvement in training and up-skilling, the initiative is going in the right direction. While funding seems adequate, co-operation among governmental units and employers should be enhanced to make the most of the programme. Recent moves in this area are a positive move in the direction of giving employers a larger role, for example by directly funding employers to deliver skills provision through Employer Ownership Pilot funding - extended to $£ 340$ million at Autumn Statement 2012. Local Enterprise Partnerships has also been given a larger strategic role in the skills system to help direct skills provision to meet local employers needs.

It is vital to raise awareness - currently mostly confined to large and public enterprises - of the programmes to support youth employment. Available evidence suggests that national campaigns to raise awareness have not proven effective (UKCES, 2011a). Well established initiatives tend to be better known. Consequently, the government could build on existing technology and links with business to promote youth employment at a more industry specific and local level. Further involvement of local authorities, which have good knowledge of local social and labour market conditions could help in that respect. A simplification of the training and apprenticeship systems would also be warranted, provided that support 
for the various workers and employers' needs is guaranteed. The wide variety and complexity of funding, the re-branding of programmes and the multiplicity of stakeholders, along with the large number of qualifications, makes it difficult for employers to understand, find and undertake the practices fitting their needs. In this respect the UKCES (2008) laid out proposals of simplification endorsed by the government.

\section{Integration of university graduates into the labour market also deserves attention}

Enhancing the work readiness of school leavers along the entire education ladder is more crucial than ever in the current context of youth under-employment. The Youth Inquiry (UKCES, 2012) shows that over the past decade graduates have competed with non-graduates in the take-up of low-skill positions. Even though tertiary educational attainment is an advantage, it is of paramount importance that graduates acquire qualifications and skills that correspond to the needs of the labour market and enhance career prospects. The crisis is likely to exacerbate the issue of skill-mismatch among graduates and to put them at risk of long-term unemployment and disconnection from the labour market. To facilitate the transition to work for graduates, the United Kingdom has launched the Graduate Guarantee, granting graduates access to internships, training or guidance to become self-employed. In addition, the Department for Business, Innovation and Skills (BIS) manages the Graduate Talent Pool website, useful for posting of and application to internships for tertiary students.

Only a quarter of employers recruit young people directly from school (UKCES, 2011a). Previous experience is cited as a key factor for recruitment by almost one quarter of employers. This requirement along with the widespread use of informal recruitment methods can put young people at a serious disadvantage, preventing them from gaining experience and building their own social capital, with severe consequences on social mobility.

Employers can support young people in several ways. There is a large demand of interaction with business among students, which could be met by employers through the proactive offer of visits to enterprises, career advice, mock interviews or business games, such as company-led workshops or competitions on real business cases. These activities would allow young people to engage with the business world, build-up their own social capital and make informed choices at their entry in the labour market. They could also count as valuable assets for recruitment purposes. Selection and hiring practices still appear not very transparent and too much reliant on informal channels. Parental background still has a major influence on school choice and employment chances, so that opportunities of work engagement are not evenly distributed among school-leavers. In order to level the playing field among young people, local authorities should co-operate with the schooling system to strengthen connections with enterprises, for instance through internet portals, social media or other communication tools to manage student-employer engagement activities.

Better welfare and labour market policies have the potential to raise the employability of individuals. Smooth reallocation of labour from less to more productive activities will support output growth. A workforce with enhanced skills will contribute to the development of high productivity activities. The availability of skilled workers may foster entrepreneurship and encourage firms to produce and create jobs. Even so, labour market policies can only contribute significantly to increasing employment in association with other policies. Weak demand for labour resulting from slow economic growth could prevent the expansion of employment which should result from enhanced work incentives and ALMPs (Immervoll and Pearson, 2009). The creation of significant numbers of high-quality jobs, which is decisive to reduce inequality, requires a competitive and innovative, growth-oriented economy. 


\section{Bibliography}

Arulampalam, W. (2000), "Is Unemployment Really Scarring? Effects of Unemployment Experiences on Wages”, Institute for the Study of Labour (IZA) Discussion Paper, No. 189, Bonn.

Banks, J., R. Blundell, A. Bozio and C. Emmerson (2011), "Disability, health and retirement in the United Kingdom”, Institute for Fiscal Studies Working Paper W11/12, February.

Bell, D. \& D. Blanchflower (2010), UK Unemployment in the Great Recession, National Institute Economic Review, Vol. 214, pp. R3-R25.

Benzie, M., A. Harvey, K. Burningham, N. Hodgson and A.Siddiqi (2011), "Vulnerability to heat waves and drought. Case studies of adaptation to climate change in south-west England", Joseph Rowntree Foundation, York.

Black, D.C. and D. Frost (2011), Health at work - an independent review of sickness absence, Department for Work and Pensions, London.

Bohnke, P. (2006), “Einkommensarm, aber beziehungsreich”, In: Alber, J., Merkel, W. (Hg.), Europas Osterweiterung: Das Ende der Vertiefung?, Berlin: Edition Sigma, S. pp. 107-134.

Bordo, M.D. and C. M. Meissner, "Does Inequality Lead to a Financial Crisis?", NBER Working Paper, No. 17896.

Bowen, A. and J. Rydge (2011), "Climate-Change Policy in the United Kingdom", OECD Economics Department Working Papers, No. 886, OECD publishing, Paris.

Brewer, M., Browne, J. and Joyce, R. (2012), "Child and working-age poverty from 2010 to 2020", Institute for Fiscal Studies Commentary C121.

Cam, S. (2012), "Involuntary part-time workers in Britain: evidence from the labour force survey", Industrial Relations Journal 43:3, pp. 242-259.

Card, D., J. Kluve and A. Weber (2010), “Active Labour Market Policy Evaluations: A Meta-Analysis”, The Economic Journal, 120 (November), pp. F452-F477.

Causa, O. and C. Chapuis (2009), "Equity in Student Achievement across OECD countries: An Investigation of the Role of Policies", OECD Economics Department Working Papers, No. 708, OECD publishing, Paris.

Chowdry, H., C. Crawford, L. Dearden, A. Goodman, and A. Vignoles (2010), "Widening participation in higher education: analysis using linked administrative data", IFS Working Papers 10/04, Institute for Fiscal Studies, London.

Clark, A. E. (2003). Unemployment as a social norm: Psychological evidence from panel data. Journal of Labor Economics, No. 21, pp. 323-351.

Cribb, J., R. Joyce and D. Phillips (2012), "Living Standards, Poverty and Inequality in the UK: 2012", Institute for Fiscal Studies Commentary C124, London. 
Cuhna, F. and J. Heckman (2010), "Investing in Our Young People”, NBER Working Paper, No. 1620.

Daguerre, A. and D. Etherington (2009), "Active labour market policies in international context: what works best? Lessons for the UK”, Department for Work and Pensions Working Paper, No. 59.

DCLG (2012), "Making every contact count, A joint approach to preventing homelessness", Department for Communities and Local Government, August.

DEFRA (2012), "Company Social Tariffs: Guidance to water and sewerage undertakers and the Water Services Regulation Authority under Section 44 of the Flood and Water Management Act 2010", Department for Environment, Food and Rural Affairs, London.

DWP (2010a), "Universal Credit: welfare that works - Impact Assessment”, Department for Work and Pensions, London.

DWP (2010b), "Income Related Benefits: Estimates of Take-Up in 2008-2009”, Department for Work and Pensions, London.

DWP (2011), "Universal Credit: welfare that works - Impact Assessment" (revised), Department for Work and Pensions, London.

DWP (2012), "Impacts and Costs and Benefits of the Future Jobs Fund", Department for Work and Pensions, London.

Faccini, R. and C. Hackworth (2010), "Changes in output, employment and wages during recessions in the United Kingdom", Bank of England Quarterly Bulletin 2010 Q1.

Finn, D. and A. Tarr (2012), "Implementing Universal Credit: will the reforms improve the service for users?", Centre for Economic and Social Inclusion / Joseph Rowntree Foundation.

Fleche, S., C. Smith and P. Sorsa (2011), "Exploring Determinants of Subjective Wellbeing in OECD countries: Evidence from the World Value Survey", OECD Economics Department Working Papers, No. 921, OECD publishing, Paris.

Goldsmith, A., Veum, J. R., Darity, W. J. (1996): The Impact of Labor Force History on Self-Esteem and its Component Parts, Anxiety, Alienation and Depression. Journal of Economic Psychology, 17(2), pp. 183-220.

Goodman, A. and B. Sianesi (2005), "Early education and children's outcomes: how long do the impacts last?", Fiscal Studies, Vol. 26, No. 4, Institute for Fiscal Studies, London.

Gregg, P. and E. Tominey (2005), "The wage scar from male youth unemployment”, Labour Economics 12 (2005), pp. 487-509.

Hanushek, E.A. and L. Woessmann (2007), "The Role of School Improvement in Economic development", NBER Working Paper, No. 12832, National Bureau of Economic Research, Cambridge MA.

Harrington, M. (2010), An Independent Review of the Work Capability Assessment.

Harrington, M. (2011), An Independent Review of the Work Capability Assessment-year two. 
Hills (2012), Getting the measure of fuel poverty, Final Report of the Fuel Poverty Review, CASE report, No. 72, London.

HM Government (2011a), "Water for Life”, London.

HM Government (2011b), Laying the Foundations: A Housing Strategy for England.

HM Government (2011c), Strategy for Social Mobility.

HM Government (2012), Strategy for Social Justice.

HMRC (2012), “The Exchequer effect of the 50 per cent additional rate of income tax", HM Revenue and Customs, March.

HM Treasury (2006), Leitch Review of Skills. Prosperity for All in the Global Economy - World Class Skills, HMSO, Norwich.

HM Treasury (2012), "Impact on households: distributional analysis to accompany the Autumn Statement 2012”, London.

Hoeckel, K., S. Field and W.N. Grubb (2009), Learning for Jobs. The OECD Review of Vocational Education and Training. Switzerland, OECD publishing, Paris.

Hopkins, R., L. Stokes, and D. Wilkinson (2010), "Quality, Outcomes and Costs in Early Years Education”, mimeo National Institute of Economic and Social Research.

IMF (2007), “Globalization and Inequality”, World Economic Outlook, IMF, Washington, pp. 31-65, October.

Immervoll, H. and M. Pearson (2009), "A Good Time for Making Work Pay? Taking Stock of In-Work Benefits and Related Measures across the OECD", OECD Social, Employment and Migration Working Papers, No. 81, OECD Publishing.

Jahoda, M. (1982). Employment and unemployment-A social psychological analysis. Cambridge, UK: Cambridge University Press.

Jin, W., Levell, P. and Phillips, D. (2010), “A survey of the UK benefit system", Institute for Fiscal Studies Briefing Note, No. 13, 2000, revised 2010.

Jin, W., R. Joyce, D. Phillips and L. Sibieta (2011), "Poverty and Inequality in the UK: 2011", Institute for Fiscal Studies Commentary C118.

Kenway, P. (2008), “Addressing in-work poverty”, Joseph Rowntree Foundation, York.

Kierzenkowski, R. and I. Koske (2012), "Less Income Inequality and More Growth - Are they Compatible? Part 8. The Drivers of Labour Income Inequality - A Literature Review", OECD Economics Department Working Papers, No. 931, OECD publishing, Paris.

Kluve, J. (2010), "The effectiveness of European active labor market programs", Labour Economics 17 (2010), pp. 904-918. 
Kumhof, M. and R. Rancière (2010), "Inequality, Leverage and Crises”, International Monetary Fund Working Paper, No. 10/268.

Laustsen, J. (2008), "Energy efficiency requirements in building codes, energy efficiency policies for new buildings", International Energy Agency Information Paper in support of the G8 Plan Of Action.

Lucchino, P., C. Rosazza-Bondibene and J. Portes (2012), "Examining the relationship between immigration and unemployment using National Insurance Number registration data", National Institute of Economic and Social Research Discussion Paper, No. 386.

Machin, S. and A. Vignoles (2006), "Education Policy in the UK", Centre for the Economics of Education Discussion Paper, No. 57, London.

Martin, B. and R. Rowthorn (2012), "Is the British economy supply constrained II? A renewed critique of productivity pessimism", Centre for Business Research, University of Cambridge.

Merrell, C., P. Tymms, and P. Jones (2007), "Changes in Children's Cognitive Development at the Start of School 2000-2006”, EARLI Conference, Budapest.

OBR (2012), Office for Budget Responsibility: Economic and fiscal outlook, December.

OECD (2005a), Babies and Bosses - Reconciling Work and Family Life (Volume 4): Canada, Finland, Sweden and the United Kingdom, OECD publishing, Paris.

OECD (2005b), OECD Employment Outlook 2005, Chapter 4, OECD publishing, Paris.

OECD (2007a), Offshoring and Employment: Trends and Impacts, OECD publishing, Paris.

OECD (2007b), Benefits and Wages, OECD publishing, Paris.

OECD (2007c), OECD Economic Surveys: United Kingdom, OECD publishing, Paris.

OECD (2010a), Health Care Systems: Efficiency and Policy Settings, OECD publishing, paris.

OECD (2010b), Sickness, Disability and Work: Breaking the Barriers, A Synthesis of Findings across OECD countries, OECD publishing, Paris.

OECD (2010c), Off to a Good Start? Jobs for Youth, OECD publishing, Paris.

OECD (2011a), OECD Economic Surveys: United Kingdom, OECD publishing, Paris.

OECD (2011b), How's Life?: Measuring well-being, OECD publishing, Paris.

OECD (2011c), Divided We Stand: Why Inequality Keeps Rising, OECD publishing, Paris.

OECD (2011d), Education at a Glance, OECD publishing, Paris.

OECD (2011e), Doing Better for Families, OECD publishing, Paris.

OECD (2012a), Gender Equality in Education, Employment and Entrepreneurship: Final Report to the Ministerial Council Meeting 2012, OECD publishing, Paris. 
OECD (2012b), Sick on the Job? Myths and Realities about Mental Health and Work, Mental Health and Work, OECD publishing, Paris.

OECD (2013), "Mental Health and Work: The United Kingdom”, OECD publishing, Paris, forthcoming.

OFT (2012), "Home insulation, A report on the Call for Evidence carried out by the OFT", London.

Olivetti, C. and B. Petrongolo (2008), "Unequal Pay or Unequal Employment? A Cross-Country Analysis of Gender Gaps", Journal of Labor Economics, University of Chicago Press, Vol. 26(4), pp. 621654 , October.

ONS (2011), 2011 Annual Survey of Hours and Earnings (SOC 2000), Office for National Statistics.

ONS (2012) "Measuring National Well-Being: Summary of proposed domains and measures", Office for National Statistics.

Pareliussen, J. (2013), "Work incentives and Universal Credit - reform of the benefit system in the United Kingdom", OECD Economics Department Working Papers, No. 1033, OECD publishing, Paris.

RWI Essen (2005), "Study on the effectiveness of ALMPs", Research project for the European Commission, DG Employment, Social Affairs and Equal Opportunities, Final report.

Slater, H., N. Davies, and S. Burgess (2009), "Do teachers matter? Measuring the variation in teacher effectiveness in England", Centre for Market and Public Organisation Working Paper 09/212, University of Bristol.

Stiglitz, J.E., A. Sen and J.P. Fitoussi (2009), Report by the Commission on the Measurement of Economic Performance and Social Progress.

Sutherland, D., R. Price, I. Joumard and C. Nicq (2007), "Performance Indicators for Public Spending Efficiency in Primary and Secondary Schools", OECD Economics Department Working Papers, No. 546, OECD publishing, Paris.

Sutherland, D., R. Price, and F. Gonand (2009), "Improving Public Spending Efficiency in Primary and Secondary Education", OECD Journal: Economic Studies, Vol. 2009, OECD publishing, Paris.

di Tella, Rafael \& MacCulloch, Robert J. \& Oswald, Andrew J., 2001. "The Macroeconomics of Happiness", The Warwick Economics Research Paper Series (TWERPS) 615, University of Warwick, Department of Economics.

UKCES (2008), Simplification of Skills in England: Expert Advice to Government on Simplification of the English Post-compulsory Skills System for Employers, UKCES, London.

UKCES (2011a), The Youth Inquiry: Employers' Perspectives on Tackling Youth Unemployment, UKCES, London.

UKCES (2011b), UK Commission's Employer Skills Survey 2011: England Results, UKCES, London.

UKCES (2012), The Youth Employment Challenge, UKCES, London. 
Venn, D. (2012), "Eligibility Criteria for Unemployment Benefits: Quantitative Indicators for OECD and EU Countries", OECD Social, Employment and Migration Working Papers, No. 131, OECD publishing, Paris.

Walker, A. (2009), The Independent Review of Charging for Household Water and Sewerage Services, Final Report, London.

Walker, I. and Y. Zhu (2008), "The College Wage Premium and the Expansion of Higher Education in the UK”, University College Dublin Working Papers, No. 200817.

Work and Pensions Committee (2011), Sixth Report, "The role of incapacity benefit reassessment in helping claimants into employment", London. 
ECO/WKP(2013)26

\section{WORKING PAPERS}

The full series of Economics Department Working Papers can be consulted at www.oecd.org/eco/workingpapers/

1033. Work incentives and Universal Credit - reform of the benefit system in the United Kingdom (March 2013) by Jon Kristian Pareliussen

1032. Strengthening social cohesion in Luxembourg: making efficiency and equity go hand in hand (March 2013) by Jean-Marc Fournier and Clara Garcia

1031. The price of oil - Will it start rising again?

(March 2013) by Jean-Marc Fournier, Isabell Koske, Isabelle Wanner and Vera Zipperer

1030. The system of revenue sharing and fiscal transfers in China

(February 2013) by Xiao Wang and Richard Herd

1029. The declining competitiveness of French firms reflects a generalised supply-side problem (February 2013) by Hervé Boulhol and Patrizio Sicari

1028. Do the overall level and dispersion of socio-economic background measures explain France's gap in PISA scores?

(February 2013) by Hervé Boulhol and Patrizio Sicari

1027. Labour market performance by age groups: a focus on France

(February 2013) by Hervé Boulhol and Patrizio Sicari

1026. Moving towards a single labour contract: pros, cons and mixed feelings

(February 2013) by Nicolas Lepage-Saucier, Juliette Schleich and Etienne Wasmer

1025. Boosting productivity in Australia

(January 2013) by Vassiliki Koutsogeorgopoulou and Omar Barbiero

1024. Housing, financial and capital taxation policies to ensure robust growth in Sweden

(January 2013) by Müge Adalet McGowan

1023. Labour market and social policies to foster more inclusive growth in Sweden

(January 2013) by Stéphanie Jamet, Thomas Chalaux and Vincent Koen

1022. Educational attainment and labour market outcomes in South Africa, 1994-2010 (January 2013) by Nicola Branson and Murray Leibbrandt

1021. Education quality and labour market outcomes in South Africa

(January 2013) by Nicola Branson and Murray Leibbrandt

1020. Do policies that reduce unemployment raise its volatility? Evidence from OECD countries (January 2013) by Alain de Serres and Fabrice Murtin

1019. Slovakia: A catching up euro area member in and out of the crisis (January 2013) by Jarko Fidrmuc, Caroline Klein, Robert Price and Andreas Wörgötter 
1018. Improving the fiscal framework to enhance growth in an era of fiscal consolidation in Slovakia (January 2013) by Caroline Klein, Robert Price and Andreas Wörgötter

1017. Investing efficiently in education and active labour market policies in Slovakia (January 2013) by Caroline Klein

1016. The performance of road transport infrastructure and its links to policies (January 2013) by Henrik Braconier, Mauro Pisu and Debra Bloch

1015. The US labour market recovery following the great recession (January 2013) by Wendy Dunn

1014. Why do Russian firms use fixed-term and agency work contracts? (December 2012) by Larisa Smirnykh and Andreas Wörgötter

1013. The Equity implications of fiscal consolidation (December 2012) by Lukasz Rawdanowicz, Eckhard Wurzel and Ane Kathrine Christensen

1012. The Dutch labour market: preparing for the future (December 2012) by Mathijs Gerritsen and Jens Høj

1011. Reforming policies for the business sector to harvest the benefits of globalisation in the Netherlands

(December 2012) by Mathijs Gerritsen and Jens Høj

1010. Health care reform and long-term care in the Netherlands (December 2012) by Erik Schut, Stéphane Sorbe and Jens Høj

1009. Enhancing the inclusiveness of the labour market in Belgium (December 2012) by Jens Høj

1008. Reducing poverty in Estonia through activation and better targeting (December 2012) by Sarah Flèche and Artur Radziwill

1007. Matching skills and jobs in Estonia (December 2012) by Lilas Demmou

1006. Debt and macroeconomic stability: An overview of the literature and some empirics (December 2012) by Douglas Sutherland and Peter Hoeller

1005. Debt and macroeconomic stability: Debt and the business cycle (December 2012) by Volker Ziemann

1004. Debt and macroeconomic stability: Case studies (December 2012) by Rossana Merola

1003. Debt and macroeconomic stability (December 2012) by Douglas Sutherland, Peter Hoeller, Rossana Merola and Volker Ziemann

1002. Reducing greenhouse gas emissions in a cost effective way in Switzerland. (December 2012) by Anita Wölfl and Patrizio Sicari 